\title{
THE LIABILITY OF PROVIDERS OF Mental Health Services in Negligence
}

\section{ANTHONY GRAY*}

In Hunter and New England Local Health District v McKenna the High Court considered the question of the liability in tort of a mental health provider for the actions of someone whom it had briefly treated. After involuntarily detaining the individual under relevant legislation, the service released the individual into the care of a friend. The person released killed his friend. The High Court allowed an appeal against a finding of the New South Wales Court of Appeal that the mental health service provider had owed, and had breached, legal obligations to the family of the person killed, denying compensation to the family on the basis that the service provider did not owe family members a duty of care. It will be argued that the High Court was wrong to deny that a mental health service provider could owe, or did owe, a duty of care to victims of those to whom the service provider provided services. The Court reached its decision utilising reasoning contrary to that of other cases which have involved questions of the liability of public authorities. The decision travels the well-worn path of denying that a public authority owes a duty of care to the public that it serves by asserting the inconsistency of obligations more apparent than real. The decision shows judicial reluctance to hold public authorities to the legal standards expected of other service providers, a reluctance that must be challenged.

\section{INTRODUCTION}

The law continues to struggle with the application of negligence principles in the context of loss caused by public authorities. This is relevant to the focus of the current article, since mental health services are in almost all cases provided by public authorities. Until the 1930s the law was content to accept

\footnotetext{
* Professor, USQ School of Law and Justice. Thanks to an anonymous reviewer for constructive comments on an earlier draft, and the editorial team for a very thorough editing process.
} 
that certain categories of relationship gave rise to civil obligations recognised by the law, ${ }^{1}$ apply strict rules forbidding recovery in other categories of case, ${ }^{2}$ but deny a generalised duty of care. This changed in 1932 upon acceptance of a generalised duty of care principle based on the concept of reasonable foreseeability and the 'neighbours' principle, ${ }^{3}$ together with statutory reform. ${ }^{4}$ The difficulty has been that at least in some circumstances, the Donoghue principle is seen to provide, or at least to raise fears of, too much liability, or open-ended liability which might have undesirable social consequences. ${ }^{5}$ This objection has sometimes generally, ${ }^{6}$ and sometimes in relation to particular categories of case, led to the development of principles that make it harder in particular cases to successfully bring an action. Examples of the latter have involved claims of 'nervous shock', ${ }^{7}$ claims for purely financial loss, ${ }^{8}$ and

${ }^{1}$ Heaven v Pender (1882-83) LR 11 QBD 503.

${ }^{2}$ For example, the doctrine of common employment makes it more difficult for employees to successfully sue their employers, and the defence of contributory negligence applies as a complete defence: Butterfield v Forrester (1809) 103 ER 926; Priestley v Fowler (1837) 3 Mees and Wels 1; 150 ER 1030. For a case of non-liability of highway authorities with respect to non-feasance see: Parsons $v$ The Vestry of St. Matthew, Bethnal Green (1867-68) LR 3 CP 56, 60 (Willes J); Buckle v Bayswater Road Board (1936) 57 CLR 259. For a denial that a property owner owes a duty of care to users of a nearby road, with respect to straying animals not known to be dangerous see: Searle v Wallbank [1947] AC 341; State Government Insurance Commission v Trigwell (1979) 142 CLR 617. For a denial of a claim by one person based on the death of another: Baker v Bolton (1808) 1 Camp 493; 170 ER 1033; Woolworths Ltd v Crotty (1942) 66 CLR 603.

${ }^{3}$ Donoghue v Stevenson [1932] AC 562.

${ }^{4}$ For example, the reform embodied in the legislation known colloquially as 'Lord Campbell's Act' to overcome most of the impact of the decision in Baker $v$ Bolton (1808) 1 Camp 493; 170 ER 1033; and see generally Peter Handford, 'Lord Campbell and the Fatal Accidents Act' (2013) 129 The Law Quarterly Review 420; in the Wrongs Act 1958 (Vic) s 24A (abolition of doctrine of common employment) and in the civil liability legislation in some jurisdictions following the insurance 'crisis' of the early 21 ${ }^{\text {st }}$ century: eg Civil Liability Act 2002 (NSW) and other state equivalents.

${ }^{5}$ In other words, 'liability in an indeterminate amount, for an indeterminate time to an indeterminate class': Ultramares Corp v Touche, 174 NE 441, 444 (Cardozo J) (NY Ct App, 1932).

${ }^{6}$ For example, through the use of the notion of 'proximity' as a control mechanism Gala $v$ Preston (1991) 172 CLR 243, or the explicit consideration of policy reasons (if any) for the denial of a duty of care: Anns v Merton London Borough Council [1978] AC 728; Caparo Industries Plc v Dickman [1990] 2 AC 605. Subsequently proximity was rejected: Hill v Van Erp (1997) 188 CLR 159 (acknowledging that the use of proximity was not identical in United Kingdom and Australian law). More recently the use of concepts such as 'control' and 'vulnerability' have been adopted: Perre v Apand Pty Ltd (1999) 198 CLR 180.

${ }^{7}$ Examples of 'control mechanisms' used here have included the concept of a person with normal fortitude, the concept of a 'sudden shock' and concepts of direct perception and immediate aftermath: Alcock v Chief Constable of South Yorkshire Police [1992] 1 AC 310. Subsequently these fell out of favour in the common law: Tame $v$ New South Wales (2002) 211 CLR 317. 
claims against public authorities. ${ }^{9}$ The recent High Court decision which provoked the analysis and criticism in this article - Hunter and New England Local Health District $v$ McKenna ('McKenna') ${ }^{10}$ — involved both the first and third types of these 'difficult' cases: that is, a claim for nervous shock and a claim against a public authority. The High Court has also noted that it is 'exceptional' to find one person liable for the actions or omissions of another, ${ }^{11}$ and traditionally has distinguished between actions and omissions. That is also a feature of the current context.

This article is structured as follows. Under heading II below important details of the relevant case, and the reasoning employed by the Court of Appeal and High Court, are discussed. Under heading III the case is placed in its context. It is the kind of case that would typically be brought against a public authority. There is a long history of the court treating cases against public authorities differently from other cases. Even today, there are suggestions that the principles applied to public authorities should differ from those applicable to other bodies. Utilitarian policy arguments, fears of indeterminate liability or suggestions of inconsistent obligations are often raised. Equivalent authorities in the United Kingdom and United States are considered, specifically on the question of policy arguments regarding public authority liability, possible inconsistency of obligations, and indeterminacy fears. This does not imply that negligence law in Australia and those other jurisdictions is the same, or should be the same. Clearly, there are major differences in the law of

${ }^{8}$ For instance, a requirement of an assumption of responsibility and (reasonable) reliance: Hedley Byrne \& Co Ltd v Heller \& Partners Ltd [1964] AC 465.

${ }^{9}$ For example, in the past distinctions have been made between policy and operational decisions (public authorities enjoying virtual immunity from suit for the former kind of decision) and the so-called Wednesbury unreasonableness principle has been used to determine the liability of a public authority: Romeo v Conservation Commission (NT) (1998) 192 CLR 431, 443 (Brennan CJ) (although cf Civil Liability Act 2002 (NSW) s 43A; Stovin v Wise [1996] AC 923; and the fact that non-feasance was not actionable (overturned in Australia in Brodie v Singleton Shire Council (2001) 206 CLR 512 (this often assisted public authorities). Legislation abolishing past Crown immunity from suit includes the Petition of Rights Act 1860 (UK) and Crown Proceedings Act 1947 (UK), Judiciary Act 1903 (Cth) s 64, Claims Against the Government and Crown Suits Act 1912 (NSW) s 4; Crown Proceedings Act 1980 (Qld) s 8; Crown Proceedings Act 1958 (Vic) s 23; Crown Proceedings Act 1972 (SA) s 10; Crown Suits Act 1947 (WA) s 5; Supreme Court Civil Procedure Act 1932 (Tas) s 64. These legislative developments indicate a significant change in how the law regards liability of public authorities, and whether they should be subject to special rules, or subject to the same rules as other organisations, and individuals.

${ }^{10}$ (2014) 253 CLR 270.

${ }^{11}$ Smith $v$ Leurs (1945) 70 CLR 256, 262 (Dixon J) (excepting vicarious liability). See also Michael $v$ Chief Constable South Wales Police [2015] 2 WLR 343, 366 [97] (Lord Toulson, with whom Lord Neuberger, Lord Mance, Lord Reed and Lord Hodge agreed). 
negligence between Australia and the United Kingdom, for example. ${ }^{12}$ Under heading IV the reasoning employed by the High Court in McKenna is considered in more depth. It is concluded that the decision is weak because of an incomplete consideration of relevant legislation, assumptions about the effect of decisions that is at the level of speculation rather than validated claim, and an apparent keenness to find an inconsistency of obligations which does not in fact exist.

\section{Significant Facts, Decision of Court of ApPEAL AND HIGH COURT}

Mr Pettigrove had suffered mental illness for at least 20 years. He had suffered from chronic paranoid schizophrenia and was being treated for this condition in regional Victoria. While in New South Wales with a friend Rose, he was taken by ambulance to the hospital, primarily because he was experiencing 'physical jerks'. ${ }^{13}$ Upon Pettigrove's arrival at $4.30 \mathrm{am}$, a hospital doctor contacted a Dr Coombes who advised the doctor to complete the documentation to allow Pettigrove to be involuntarily detained in the hospital under that state's mental health legislation, and to give Pettigrove an injection of an anti-psychotic drug and a sedative. ${ }^{14}$ In order that Pettigrove be so detained, it was necessary to obtain appropriate authorisations. Dr Coombes, who observed Pettigrove at the hospital, signed a document to the effect that Pettigrove was mentally ill within the meaning of the relevant Act, as did the superintendent of the hospital at the time. The form was completed by a duty doctor, Dr Saw, who noted that Pettigrove was suffering suicidal ideation, and seemed to question whether Pettigrove was suffering psychotic depression by writing a question mark after those words in his notes. His notes included the words 'concern harm to self/others'. Dr Saw indicated on the forms that the patient's detention was necessary for his own protection and

\footnotetext{
${ }^{12}$ For example, while the United Kingdom applies the three-stage Caparo approach (derived from Caparo Industries Plc v Dickman [1990] 2 AC 605), including considerations of proximity, the use of proximity in Australia fell into disfavour as evidenced by Perre $v$ Apand (1998) 198 CLR 180. Australian law does not apply the three stage Caparo approach, preferring instead a salient features approach to questions of negligence liability: Graham Barclay Oysters Pty Ltd v Ryan (2002) 211 CLR 540. Some argue that the distinction between proximity and salient features is marginal: Hill v Van Erp (1997) 188 CLR 159, 178 (Dawson J), 190 (Toohey J). Australian (common) law has abolished past immunity for acts of nonfeasance: Brodie v Singleton (2001) 206 CLR 512.

${ }^{13}$ McKenna (2014) 253 CLR 270.

${ }^{14}$ This summary of facts is obtained from the judgment of Macfarlan JA (with whom Beazley P agreed) in the New South Wales Court of Appeal: [2013] NSWCA 476, [13]. The High Court did not refer to the facts in detail in its judgment: ibid.
} 
that of others. A form that Dr Coombes signed confirmed that Pettigrove had presented with 'depression (and was) psychotic', and that the principal diagnosis was 'exacerbation of chronic paranoid schizophrenia' ${ }^{15}$

Later that morning, an Assessment of Current Presentation form was completed by a clinical nurse. The assessment reiterated the 'physical jerks' symptoms and explained them as psychotic phenomena. It recorded the patient reporting hearing voices that bothered him, and that he had a history of not taking his medication. ${ }^{16}$ Another form completed by an unidentified nurse, rated Pettigrove two out of seven on an 'overactive, aggressive, disruptive or agitated' scale and three out of seven on a 'problems with hallucinations and delusions' scale. ${ }^{17} \mathrm{~A}$ similar form completed by another nurse the following day scored Pettigrove zero and one respectively on these criteria. ${ }^{18}$

The legislation at the time required that any person involuntarily detained under mental health legislation had to be examined within 12 hours of admission by the hospital's medical superintendent. ${ }^{19}$ They could be kept in detention only if the superintendent certified that the person was mentally ill or disordered. The superintendent, $\mathrm{Dr} \mathrm{Wu}$, stated that Pettigrove was mentally ill, noting that she had observed 'bizarre behaviour, inappropriate eye movement plus verbal activity, suicidal ideation, unresponsive at times, and concern harm to self/others', with a conclusion of 'schizophrenia'. The Mental Health Act 1990 (NSW) required a further review to be conducted by a psychiatrist. Dr Coombes did this, concluding that Pettigrove was mentally ill. ${ }^{20}$ His notes recorded his awareness of Pettigrove's long history of paranoid schizophrenia, the doctor having sighted Pettigrove's medical history. This medical history was extensive, and included Pettigrove's history of noncompliance with medication, jumping in front of trucks, lying face down on roadways, talking to himself, and likely auditory hallucinations. ${ }^{21} \mathrm{Dr}$ Coombes noted that the patient looked perplexed and bewildered, and had not taken medication for at least 7 months. He concluded that the patient should be detained overnight, then transferred to his mother's home in rural Victoria with his friend Rose. Dr Coombes then arranged for Pettigrove to be taken from the assessment area to the secured mental health unit, arranging two 'solid males from emergency'.

\footnotetext{
${ }^{15}$ Ibid [17].

${ }^{16}$ Ibid [18].

${ }^{17}$ Ibid [19].

${ }^{18}$ Ibid.

${ }^{19}$ Mental Health Act 1990 (NSW) s 29. Ibid.

${ }^{20}$ Ibid [22].

${ }^{21}$ Ibid [28]-[31].
} 
On the day that Pettigrove was involuntarily detained, Dr Coombes spoke with Pettigrove, Pettigrove's mother, and Rose. He discussed various treatment options with Pettigrove's mother and Rose. Dr Coombes noted that Pettigrove's mother wanted him home in Victoria, and that Rose was happy to drive him there. It was agreed that Pettigrove would be detained in the New South Wales hospital overnight, and that Rose would then drive with Pettigrove to his mother's home in Victoria, near where he had been receiving medical treatment. This would involve a car trip of almost 1000 kilometres. Dr Coombes expressed in his notes a strong preference for the pair to travel a route with psychiatric services along it, so that they could receive assistance if needed. ${ }^{22}$

Following that meeting, Dr Coombes completed another form. He ticked boxes indicating that there was no foreseeable risk of Pettigrove inflicting harm on himself or others. ${ }^{23}$ He again referred to the patient's long-term schizophrenia, noting that the patient was 'not obviously hallucinating'. He indicated that there was no apparent risk to Pettigrove or to others, and that Pettigrove was to be given no medication upon discharge. ${ }^{24}$ This was apparently because Pettigrove and Rose would be sharing the driving, and $\mathrm{Dr}$ Coombes did not want to make Pettigrove drowsy. If Pettigrove had been given a depot injection prior to commencement of the journey, it would have reduced the risk of 'something untoward' happening on the journey.

During the night in which Pettigrove was detained in the New South Wales facility, he was observed by nursing staff. They noted that he remained awake at all times during that evening, and appeared to be speaking to himself loudly. When nursing staff approached the door to his room, he would quieten. ${ }^{25}$

On the next day, Pettigrove was discharged into the care of Rose. Rose arrived at the hospital a few hours later than had been agreed. This affected their journey to Pettigrove's mother's home, since Rose's late arrival meant, significantly, that the two set off later than anticipated. This increased the risk of something going wrong during the journey, because evidence suggested that the risk of someone with paranoid schizophrenia suffering an 'attack' was higher at night than during the day. During this journey, Pettigrove started to believe that Rose had killed him in a previous life. He strangled and killed Rose in the vehicle. Subsequently Pettigrove committed suicide.

\footnotetext{
22 Ibid [23].

${ }^{23}$ Ibid [25].

${ }^{24}$ Ibid.

${ }^{25}$ Ibid [35].
} 
The legal claim was brought by members of Rose's family. His mother and sisters claimed that they had developed a psychiatric condition as a result of what had happened to Rose, and that the medical authority was liable to them in negligence. The trial judge found that the medical authority had not breached its duty of care to the family. ${ }^{26}$ The Court of Appeal found by majority (Macfarlan JA and Beazley P, Garling J dissenting) that the medical authority had breached the duty of care it owed to the family. ${ }^{27}$ The High Court found that the medical authority had not owed a duty of care to the family. ${ }^{28}$

\section{A Court of Appeal}

By a majority of $2-1$, the Court held that Rose's mother and sisters were entitled to compensation based on a breach of the (common law) duty of care owed to them by the medical authority. ${ }^{29}$ Macfarlan JA expressed the majority view, in terms with which Beazley P expressed agreement. Macfarlan JA considered the elements of a negligence action. He did so in the context of whether the medical authority had owed a duty of care to Rose, rather than whether they had owed one to members of Rose's family. The assumption was made that if the hospital had owed a duty of care to Rose, it would have owed one to his family. ${ }^{30}$

Macfarlan JA found that a duty of care had existed, noting that the trial judge had assumed that a relevant duty of care existed. The duty of care he accepted was a duty owed by the hospital to Rose to take reasonable care to prevent Pettigrove from physically harming Rose. ${ }^{31}$ He referred to indicia of a duty of care obligation owed by one to another, including: the defendant's control over the risk of harm, the degree of vulnerability of those to whom the duty is

\footnotetext{
${ }^{26}$ McKenna v Hunter \& New England Local Health District [2012] NSWDC 19.

${ }^{27}$ McKenna v Hunter \& New England Local Health District [2013] NSWCA 476.

28 McKenna (2014) 253 CLR 270.

${ }^{29}$ This was not a claim for breach of statutory duty: McKenna $v$ Hunter \& New England Local Health District [2013] NSWCA 476

${ }^{30}$ Ibid [85], based on the defendant's concession; Macfarlan JA said it was sufficient to consider whether the hospital owed a duty of care to Rose, since the hospital did not argue that the question of whether a duty of care was owed to (a) Rose and (b) his family might have different answers. The High Court cast doubt on the correctness of this approach: McKenna (2014) 253 CLR 270 [14] (French CJ, Hayne, Bell, Gageler and Keane JJ), in terms with which the present author agrees. It is not necessary to resolve this issue for present purposes.

${ }^{31}$ McKenna v Hunter \& New England Local Health District [2013] NSWCA 476, [108].
} 
said to be owed, and the consistency of the duty of care with other obligations. $^{32}$

In finding that a duty of care existed, Macfarlan JA cited the decision of the New South Wales Court of Appeal in Hunter Area Health Service v Presland ('Presland'). ${ }^{33}$ Briefly, the case there against the Hunter Area Health Service involved a psychiatric patient who had been released from its care and who then killed his brother's fiancé within six hours of release. The patient had been confined under mental health legislation. The patient sued the medical authority for releasing him when it did, claiming compensation for the mental anguish he suffered directly from the killing and consequences that flowed from it. The majority in that case found that the defendant did not owe the plaintiff a duty of care.

Macfarlan JA here relied on the dissenting judgment of Spigelman CJ in Presland, who found that a duty of care existed in that case, based on control and vulnerability. Spigelman CJ found no conflict between the asserted common law duty and the relevant obligations of authorities under the state's mental health legislation. ${ }^{34}$ The majority in Presland made it clear that its decision did not preclude an action different in kind from the one at issue there. Santow JA specifically found that an action might be brought by a third party who had suffered serious physical harm due to the actions of the person released. ${ }^{35}$

Macfarlan JA found that the medical authority had breached its duty of care. He was not satisfied that representatives of the authority could, on one day, be convinced that Pettigrove warranted being involuntarily detained under the mental health legislation, and then apparently be satisfied the very next day that the patient could be released without significant risk. Dr Coombes had not scheduled another appointment prior to release. The patient's symptoms were likely to fluctuate, so observations over just a few hours were insufficient to assess the state of mind of this psychotic patient. The admitting authorities had noted that the patient was at risk of harm to himself or others. The overnight nurses had observed the patient to be in an agitated state. Dr Coombes obviously had some concerns about the journey, but was apparently satisfied that the existence of mental health facilities along the intended path would ameliorate the risk. It was common knowledge that the danger of a psychotic episode increased at night. Dr Coombes knew it was likely that

\footnotetext{
32 Ibid [93], [104]-[105].

33 [2005] NSWCA 33.

${ }^{34}$ Ibid [35]-[41].

${ }^{35}$ Ibid [36].
} 
Pettigrove and Rose would be in the car together at night, given the length of journey involved. Dr Coombes declined to give Pettigrove a depot injection which would have reduced the risk of an incident. He knew that Pettigrove had a history of not taking medication, and had not had a depot injection for seven months prior to admission. Macfarlan JA concluded that at the time of discharge, there was a foreseeable and not insignificant risk of Pettigrove causing harm to Rose. The risk of very serious harm to Rose was high. The hospital had had the capacity to detain Pettigrove for longer and it would not have imposed an unreasonable burden upon it to do so. As regards the social utility of releasing Pettigrove, whilst the legislation did require Pettigrove to be treated with measures that were least invasive of his human rights, the Act was concerned with both the control of mental health patients undergoing treatment and the protection of the patient and others. Macfarlan JA decided that the medical authority had caused the death of Rose. In the terms of section 5D of the Civil Liability Act 2002 (NSW), its actions in releasing Pettigrove were a 'necessary condition' of the occurrence of the harm in the sense that the opportunity for Pettigrove to harm Rose arose only because of the hospital's decision to release Pettigrove. ${ }^{36}$

Garling J (dissenting) denied that a duty of care was owed. Although the parties apparently conceded that, if the hospital had owed a duty of care to Rose, it had also owed one to his family, Garling J found this concession inappropriate. The law had always taken a narrower approach to claims for psychiatric injury, a position maintained by section 30 of the Civil Liability Act 2002 (NSW). However, his main finding was that the hospital did not owe a duty of care to Rose. Garling J found that the Act was expressly focused on care, treatment and control of the mentally ill. It did not expressly refer to protection of the public, or include it as an objective to be pursued under the Act. It reflected a sentiment that those suffering from mental health issues should be treated wherever possible in community-based settings on an informal and voluntary basis; involuntary detention and treatment were a last resort.

Garling J noted the common law's general antipathy towards suggestions that one person is legally required to prevent another person from causing injury, and the important distinction between not causing harm and not preventing harm. The legal recognition of an obligation to someone such as Rose would conflict with the social obligations the hospital had to patients such as Pettigrove; for this reason no duty of care was owed. ${ }^{37}$

\footnotetext{
${ }^{36}$ McKenna v Hunter \& New England Local Health District [2013] NSWCA 476, [184]-[187].

${ }^{37}$ Ibid [257].
} 


\section{B High Court}

All five members of the High Court who were hearing the case allowed an appeal against the decision of the New South Wales Court of Appeal. ${ }^{38}$ The primary reason was the Appeal Court's finding that the hospital did not owe the plaintiffs a duty of care. ${ }^{39}$ The High Court noted the emphasis that the relevant mental health legislation placed on measures minimally invasive of a patient's rights, dignity and self-respect. Specifically, the power to involuntarily detain a mentally ill individual under the legislation could only be exercised where the medical superintendent believed that no other care of a less restrictive kind was appropriate and reasonably available. ${ }^{40}$

The High Court held that to impose a duty of care on persons such as the appellant (the hospital) would conflict with these provisions of the mental health legislation. That legislation required the focus to be exclusively on the patient whereas the common law duty would require the hospital to have regard to others with whom the patient might come into contact. Often, the risk of a mentally ill person acting irrationally would not be insignificant, and the consequences could be serious. As a result, in such cases, a decision maker would be minded to involuntarily detain, or continue to detain, a person suffering from mental illness. This common law position conflicted with clear indications in the legislation that involuntarily detention was a last resort. This conflict was fatal to the existence of the posited common law duty of care. ${ }^{41}$ Elsewhere, the High Court cast doubt on the correctness of the approach in the lower courts which had treated as equivalent a putative claim by Rose himself

\footnotetext{
${ }^{38}$ McKenna (2014) 253 CLR 270.

39 This decision was in line with the recent low success rate of plaintiffs in negligence actions in the High Court observed by Stewart and Stuhmcke and the even lower success rate of plaintiffs seeking compensation against public authorities: Pam Stewart and Anita Stuhmcke, 'High Court Negligence Cases 2000-10' (2014) 36 Sydney Law Review 585. Because the High Court decided the case on the issue of a duty of care, it did not need to consider, and did not consider, general provisions of the Civil Liability Act 2002 (NSW) regarding liability for nervous shock and provisions regarding exercise of statutory powers. As a result, given that this article primarily concerns the decision in the case and the broader context of that decision and comparable decisions, those statutory provisions will not be dwelt on here.

${ }^{40}$ On deinstitutionalisation in the mental health context, see Jonathan Bach, 'Requiring Due Care in the Process of Patient Deinstitutionalisation: Toward a Common Law Approach to Mental Health Care Reform' (1989) 98 Yale Law Journal 1153.

${ }^{41}$ McKenna (2014) 253 CLR 270, 281-2 [29]-[31]. The finding that no duty of care was owed meant that the High Court did not consider whether the duty of care had been breached, what its precise scope might be, or whether the duty of care might be indeterminate. Nor was the Court required to consider the application of other sections of the Civil Liability Act 2002 (NSW) in relation to claims for psychiatric injury and claims against public authorities.
} 
and a claim by his family. ${ }^{42}$ It hinted at indeterminacy issues, briefly raising the concern that if a duty of care was held to be owed to Rose and his relatives, it would be difficult to rule out claims by anyone with whom someone such as Pettigrove might come into contact post-release. ${ }^{43}$

\section{Precedent on the Question of Whether a Body With STATUTORY RESPONSIBILITIES OWES A DUTY OF CARE}

The above litigation should be placed in a broader context. It concerns questions of the liability of public authorities, since the overwhelming majority of mental health services are provided by public authorities. The case law in this area is deep and extensive. Public authorities are often the subject of legislation, thus frequently raising the question of whether the existence of a common law duty of care was intended by parliament to apply to them, whether such a duty would clash with statutory provisions, and whether such a duty would alter the exercise of powers or duties under the legislation in a socially harmful manner. Some argue that the common law of tort cannot and should not be applied in the context of public authorities, and that public law concepts, such as so-called Wednesbury unreasonableness, ${ }^{44}$ should be instead applied to questions of the liability of public bodies.

It should be acknowledged that the case at hand is arguably not a 'public authority case' but rather a case involving medical negligence, psychiatrists having special powers under mental health legislation. No doubt, reasonable minds will differ on this. It is the premise of this article that this is a case involving medical negligence, but a particular kind of medical negligence namely the negligence that occurs when a statutory power under the mental

\footnotetext{
42 Ibid 278 [15]. The High Court might have drawn support for this approach from the earlier decision of Chester v The Council of the Municipality of Waverley (1939) 62 CLR 1, a tragic case involving the drowning of a child in a trench dug by a Council. His mother claimed damages for a psychiatric illness she claimed she had suffered after observing her child being found in and recovered from the trench. The Court denied the woman's claim, but opined that if the son had lived but merely suffered injuries, he would have had a claim, as would any dependants of his, had he been older: 7 (Latham CJ), 11 (Rich J). It is submitted that the High Court was correct, on both occasions, to treat as separate and independent claims the claim (if any) of the immediate victim, and the claim of those who had suffered psychiatric illness as a result of the injury to the immediate victim. (This is not intended to indicate that the author agrees with the outcome in Chester, which denied to the boy's mother a claim in nervous shock on the basis that a person of normal constitution would not suffer such a psychiatric injury in such circumstances).

${ }^{43}$ McKenna (2014) 253 CLR 270, 278 [16].

${ }^{44}$ Associated Provincial Picture Houses Ltd v Wednesbury Corp [1948] 1 KB 223.
} 
health legislation ought to have been exercised in a different way. For this reason, the article argues that other cases that have considered negligence claims around the exercise or non-exercise of statutory powers are relevant to the current discussion. It is significant that the case was brought against a public authority with statutory powers and duties.

As indicated earlier, in the past the Crown, and bodies entitled to the shield of the Crown, were considered to be immune from liability in tort. This, together with an immunity from statute, was of ancient provenance, with the classic reference being to a quote in 1615 that 'the King cannot do a wrong' ${ }^{45}$ This immunity from suit was limited and then abolished in the United Kingdom in 1860 and 1947 respectively. ${ }^{46}$ Its rejection is implicitly reflected in section 64 of the Judiciary Act 1903 (Cth), and is expressed in various state laws. ${ }^{47}$ Despite this abolition, judicial reluctance to find government bodies, particularly (in this context) government bodies with statutory responsibilities, liable in tort remains strong. ${ }^{48}$ Evidence of this reluctance includes the fact

${ }^{45}$ Magdalen College Case (1615) 11 Co Rep 66, 72a; 77 ER 1235, 1243 (Lord Coke); adopted by Griffith CJ in Sydney Harbour Trust Commissioners v Ryan (1911) 13 CLR 358, 365 (Barton J to like effect, 370). If it were a word, rather than a phrase, what Coke said might be described as a contranym, because the phrase used can be interpreted in opposite directions. Specifically, it might mean that no court could find that the monarch had done a wrong, because it was not possible; alternatively it might mean that monarchs, like the rest of the population, ought not (more accurate than 'cannot') do a wrong. The suggestion of Crown immunity from liability and statute gained a footing ( $R v \operatorname{Cook}(1790) 3$ TR 519, 521.), and a strong presumption against the Crown being bound by statute was accepted and applied for many years: Province of Bombay v Municipal Corporation of the City of Bombay [1947] AC 58. There remains such a presumption in Australia, though it was weakened substantially in Bropho $v$ Western Australia (1990) 171 CLR 1. Crown immunity from suit was abolished by legislation: see Petition of Rights Act 1860 (UK) and Crown Proceedings Act 1947 (UK); Judiciary Act 1903 (Cth) s 64; William Holdsworth, 'The History of Remedies against the Crown' (1922) 38 The Law Quarterly Review 141.

46 The Petition of Rights Act 1860 (UK) and Crown Proceedings Act 1947 (UK). In 1866 the House of Lords conceded that a public body could be liable in tort: Mersey Docks \& Harbour Board Trustees v Gibbs (1866) LR 1 HL 93; Geddis v Proprietors of Bann Reservoir (1878) LR 3 App Cas 430, 455-6 (Lord Blackburn): 'it is now thoroughly well established that no action will lie for doing that which the legislature has authorised, if it be done without negligence, although it does not occasion damage to anyone; but an action does lie for doing that which the legislature has authorised, if it be done negligently'.

${ }^{47}$ Claims Against the Government and Crown Suits Act 1912 (NSW) s 4; Crown Proceedings Act 1958 (Vic) s 23; Crown Proceedings Act 1980 (Qld) s 8; Crown Proceedings Act 1972 (SA) s 10; Crown Suits Act 1947 (WA) s 5; Supreme Court Civil Procedure Act 1932 (Tas) s 64; Greg Taylor, 'John Baker's Act: The South Australian Origins of Claims-Against-theGovernment Legislation’ (2004) 27(3) University of New South Wales Law Journal 736.

48 'There may be special factors applicable to a statutory authority which negative a duty of care that a private individual would owe in apparently similar circumstances': Crimmins $v$ Stevedoring Industry Finance Committee (1999) 200 CLR 1, 34 (McHugh J). Recently a majority of the United Kingdom Supreme Court denied that a body set up as a protective 
that public authorities have enjoyed special treatment in the past, including immunity from liability for acts of non-feasance ${ }^{49}$ (such immunity abolished in Australia in 2001). ${ }^{50}$ The courts have also made a distinction between policy decisions (which enjoyed at common law ${ }^{51}$ and continue to enjoy in statute greater protection from civil action), ${ }^{52}$ and merely operational decisions, where the prospects of civil action are greater. The usual fear in the law of tort of 'floodgates litigation' appears particularly likely to be aroused in this context. The power of some public authorities is clearly very significant, creating the possibility of liability on various fronts; a wide range of individuals and organisations might be affected by what the public authority does nor does not do. ${ }^{53}$ Local authorities sometimes need to make important policy decisions that a court might be ill-equipped to review in terms of negligence liability, even if it were minded to do so and it was within judicial remit to do so. ${ }^{54}$ The defence of such actions might drain the resources of the organisation away from more positive activities, given limited public funding. ${ }^{55}$ There is evident utilitarian concern with permitting negligence claims in areas which could compromise the performance of important public functions or have implications for the greater good, including (unproductive) diversion of resources.

\footnotetext{
system with public resources should be held liable in negligence for the actions of a third party not under its control, although the body might contain defects, be at fault, or have failed to achieve its purpose/s: Michael v Chief Constable of South Wales Police [2015] 2 WLR 343, 369 [114]-[115] (Lord Toulson, with whom Lord Neuberger, Lord Mance, Lord Reed and Lord Hodge agreed).

${ }^{49}$ Gorringe v Calderdale Metropolitan Borough Council [2004] 1 WLR 1057, 1068 [38] (Lord Hoffmann), 1075-6 [65] (Lord Scott), 1080 [80] (Lord Rodger), 1087 [102] (Lord Brown).

${ }^{50}$ Brodie v Singleton Shire Council (2001) 206 CLR 512.

${ }^{51}$ Sutherland Shire Council v Heyman (1985) 157 CLR 424, 438 (Gibbs CJ), 469 (Mason J), 500 (Deane J); Pyrenees Shire Council v Day (1998) 192 CLR 330, 358 (Toohey J), cf 393 (Gummow J). The existence of a 'policy' exception was rejected by Gaudron McHugh and Gummow JJ in Brodie v Singleton Shire Council (2001) 206 CLR 512, 560.

${ }^{52}$ See, for example, Civil Liability Act 2002 (NSW) s 42; Wrongs Act 1958 (Vic) s 83; Civil Liability Act 2003 (Qld) s 35; Civil Liability Act 2002 (WA) s 5W; Civil Liability Act 2002 (Tas) s 38; Civil Law (Wrongs) Act 2002 (ACT) s 110.

53 This has been recognised as being particularly acute in relation to police investigations: Tame $v$ New South Wales (2002) 211 CLR 317, 335 (Gleeson CJ), 396 (Gummow and Kirby JJ), 418 (Hayne J); Van Colle v Chief Constable of the Hertfordshire Police [2008] 3 WLR 593.

${ }^{54}$ These factors are explored in the judgment of Lord Diplock in Home Office v Dorset Yacht Co Ltd [1970] AC 1004, 1067.

${ }^{55}$ Van Colle v Hertfordshire Police [2008] 3 WLR 593, 624 [89] (Lord Phillips), 633 [133] (Lord Brown).
} 
In the latter part of the $20^{\text {th }}$ century there developed a practice of judges applying, ${ }^{56}$ with the support of scholars ${ }^{57}$ principles of public law, particularly administrative law, to questions of the common law liability of public authorities. To some extent this practice is designed to protect public authorities from liability for their actions or omissions. ${ }^{58}$ This approach has more recently been criticised by judges ${ }^{59}$ and scholars. ${ }^{60}$ On the other hand, there are factors that point towards the same legal principles applying to public authorities as apply to other parties, at least as a general starting principle. ${ }^{61}$ For example, the rule of law, and the statutory removal of former immunity from suit for the Crown, might suggest this.

It is problematic to apply principles developed in the specific context of judicial review (assessing the legality of action and whether the authority has acted within power) to the different context of a private law claim where the

${ }^{56}$ Home Office v Dorset Yacht Co Ltd [1970] AC 1004, 1067 (Lord Diplock); Stovin v Wise [1996] AC 923, 936 (Lord Nicholls, with whom Lord Slynn agreed), 953 (Lord Hoffmann, with whom Lords Goff and Jauncey agreed); Romeo v Conservation Commission (NT) (1998) 192 CLR 431, 443 (Brennan CJ).

${ }^{57}$ Tom Cornford, Towards a Public Law of Tort (Ashgate, 2008) 142-51.

${ }^{58}$ For instance, this may be because a court is ill-equipped to revisit decisions based on a careful balancing of competing priorities and interests that the public authority's decision, act or omission may represent: John Doyle and Jonathon Redwood, 'The Common Law Liability of Public Authorities: The Interface Between Public Law and Private Law' (1999) 7 Tort Law Review 30, 34; Cornford, ibid, 208: 'public law concepts often seem to have been used to reduce the likelihood of liability'; 'a coherent, principled control mechanism has to be found for limiting this area of potential liability (public authority liability. The powers conferred on public authorities permeate so many fields that a private law duty in all cases, sounding in damages, would be (un)acceptable': Stovin v Wise [1996] AC 923, 936 (Lord Nicholls).

${ }^{59}$ Barrett v Enfield London Borough Council [2001] 2 AC 550, 571-2 (Lord Slynn, with whom Lords Nolan and Steyn agreed); X (Minors) v Bedfordshire County Council [1995] 2 AC 633, 736 (Lord Browne-Wilkinson); Phelps v Hillingdon London Borough Council [2001] 2 AC 619, 652-3 (Lord Slynn for the Court); Crimmins v Stevedoring Industry Finance Committee (1999) 200 CLR 1, 18 (Gaudron J), 35 (McHugh J), 78 (Kirby J).

${ }^{60}$ S H Bailey and M J Bowman, 'Public Authority Negligence Revisited' (2000) 59(1) Cambridge Law Journal 85 ('Bailey and Bowman'); M J Bowman and S H Bailey, 'Negligence in the Realms of Public Law - A Positive Obligation to Rescue' [1984] PL 277 ; Donal Nolan, 'Varying the Standard of Care in Negligence' (2013) 72(3) Cambridge Law Journal 651, 669; Mark Aronson, 'Government Liability in Negligence' (2008) 32 Melbourne University Law Review 44, 80; Stephen Bailey, 'Public Liability in Negligence: The Continued Search for Coherence’ (2006) 26(2) Legal Studies 155, 156: 'it seems increasingly to have been accepted that the ordinary principles of negligence normally provide sufficient flexibility to ensure that an appropriate balance is maintained between claimant and defendant public authority that takes proper account of the latter's responsibilities to act in the public interest'.

${ }^{61}$ Bailey and Bowman, above n 60, 116-7. 
remedy sought is typically damages. ${ }^{62}$ The standards of behaviour expected, and the circumstances in which an 'actionable wrong' might be found, differ ${ }^{63} \mathrm{~A}$ further consequence of doing so would be that principles applied to cases of negligence with respect to public authorities would differ from those applied to other defendants. This offends the rule of law, in the sense that the law should be applied equally. ${ }^{64}$ Alternatively, the legitimacy of a state's legal demands on its citizens may be questioned if the state is subject to different rules from those to which its citizens are subject. ${ }^{65}$ Attempts by courts to identify 'public functions', to which arguably special rules might be applied, have been abandoned due to the inherent difficulty of doing so. ${ }^{66}$ Specifically negligence law has abandoned a category-based approach ${ }^{67}$ in favour of a broad, generalised duty of care ${ }^{68}$ Categories are, however, still often useful. In the context of the application of a salient features approach, for example, the relative emphasis given to particular features will differ according to the category of case involved. The general trend of harmonisation of principle

\footnotetext{
${ }^{62}$ Cornford, above n 57, 17; Crimmins v Stevedoring Industry Finance Committee (1999) 200 CLR 1, 35 (McHugh J): 'I am unable to accept that determination of a duty of care should depend on public law concepts. Public law concepts of duty and private law notions of duty are informed by differing rationales'. See also John Doyle, 'Tort Liability for the Exercise of Statutory Powers' in Paul Finn ed, Essays on Torts (Law book, 1989) 235-6: 'there is no reason why a valid decision cannot be subject to a duty of care, and no reason why an invalid decision should more readily attract a duty of care'.

63 Peter Cane, 'Damages in Public Law' (1999) 9(3) Otago Law Review 489, 507: 'this sense of unreasonable (so-called Wednesbury unreasonableness, a public law doctrine) is stronger than that normally used in the law of tort'; John Doyle and Jonathon Redwood, 'The Common Law Liability of Public Authorities: The Interface Between Public and Private Law' (1999) 7 Tort Law Review 30, 36: 'the courts use the ultra vires test in judicial review, where the courts are concerned with the lawfulness of executive action. By contrast, common law proceedings for negligence germinate from an unrelated doctrinal base'; Roderick Bagshaw, 'Monetary Remedies in Public Law - Misdiagnosis and Misprescription' (2006) 26(1) Legal Studies 4, $18-22$.

${ }^{64}$ Albert Dicey, An Introduction to the Study of the Law of the Constitution (Macmillan and Co, 1885) 110-114; Lord Bingham, 'The Rule of Law' (2007) 66(1) Cambridge Law Journal 67, 73.

${ }^{65}$ Cornford states that in framing rules with respect to state liability in negligence, the principle that citizens must perceive the state's power over them as legitimate is important: Cornford, above n 57, 11-13.

${ }^{66}$ Coomber (Surveyor of Taxes) v Berkshire Justices (1883) 9 App Cas 61.

${ }^{67}$ Heaven $v$ Pender (1882-83) LR 11 QBD 503.

${ }^{68}$ Donoghue v Stevenson [1932] AC 562; Australian Safeway Stores Pty Ltd v Zaluzna (1987) 162 CLR 479 (abandonment of category approach to establishing a duty of care with respect to occupiers), Burnie Port Authority v General Jones Pty Ltd (1994) 179 CLR 520 (abandonment of special strict liability rules, subsumption into generalised duty of care).
} 
seems inconsistent with immunities, ${ }^{69}$ special rules or presumptions applying where public authorities are sued in negligence.

Courts have noted that generally one person (A) is not legally responsible to another (B) for failing to prevent a third party (C) from injuring B. McKenna conforms to that pattern, where the mental health authority is $\mathrm{A}$, the mental health patient Pettigrove is $\mathrm{C}$, and the family of Rose is $\mathrm{B}$. There are, however, occasional exceptions. These may be based on arguments that A controlled $\mathrm{C}^{70}$ or that 'the act of (C) could not have taken place but for' the breach of A's duty. ${ }^{71}$ While an occupier of premises is held not liable in negligence for criminal acts committed on the premises, an exception to the general rule has been held to apply where the occupier has had specific knowledge of threats or danger. ${ }^{72}$ The principle that the defendant had assumed responsibility might also apply in McKenna, given that the defendant had Pettigrove under its control (in involuntary detention) for at least some time. $^{73}$

The questions of: the extent to which a body given statutory responsibilities owes a duty of care with respect to its exercise or non-exercise of those responsibilities, and of the party to whom it owes any duty of care, are ones that have been considered in previous cases. It is instructive to note how judgments in those cases dealt with these issues In particular, questions concerning the possible inconsistency of obligations between a posited common law duty of care and statutory provisions, and concerning the policy considerations guiding judicial interpretation in this area, will be the focus of this article.

An earlier case that is relevant to the issues raised in McKenna is Sullivan $v$ Moody. ${ }^{74}$ That case concerned child welfare legislation which, inter alia, enabled a government department to act in relation to child welfare. The overriding concern guiding the exercise of its powers was the welfare of the child. The legislation included a power to investigate claims of child abuse. It

\footnotetext{
69 The word 'immunities' was used in Hill v Chief Constable of West Yorkshire) [1989] 1 AC 53, 64 (Lord Keith). Subsequent UK cases have preferred different language given arguments that 'immunity' would be contrary to the ECHR: Osman v United Kingdom [1998] ECHR 101.

${ }^{70}$ Home Office v Dorset Yacht Co Ltd [1970] AC 1004.

${ }^{71}$ Smith $v$ Leurs (1945) 70 CLR 256, 262 (Dixon J).

72 Modbury Triangle Shopping Centre Pty Ltd v Anzil (2000) 205 CLR 254, 267 (Gleeson CJ), 270 (Gaudron J), 294 (Hayne J).

${ }^{73}$ While not unknown to Australian law, it is conceded that this principle is typically found more often in United Kingdom than in Australian cases.

${ }^{74}$ (2001) 207 CLR 562.
} 
stated that where a child welfare worker acted in good faith and in accordance with the section, that worker had no legal liability for any aspect of the investigation, and that any liability that would otherwise accrue would lie against the Crown. At issue were various reports made by workers and suggesting that some fathers had abused their children, conclusions that were later shown to be false. Those fathers who had been falsely accused brought defamation actions against the child welfare workers who compiled the reports, and the State. The High Court dismissed the claim, on the basis that no duty of care was owed by the defendants to the plaintiffs; since the imposition of such a duty would be inconsistent with and/or cut across the responsibilities of the State under the Act concerning child welfare.

The Court held that the fact that a defendant owed a duty of care to a third party, or was subject to statutory obligations constraining the manner in which powers or discretions might be exercised, did not of itself rule out the possibility that it might owe a duty of care to a plaintiff. Individuals could be subject to a number of duties, provided that they were not irreconcilable. ${ }^{75}$ The Court noted, for example, that medical practitioners reporting on the condition of an individual might owe duties to more than one person. However, problems would arise when a suggested duty would give rise to inconsistent obligations; in that case the posited duty would be denied. The Court found that where public authorities were charged with conducting investigations or exercising powers in the public interest or in the interests of a specified class of persons, the law would not ordinarily subject them to a duty to have regard to the interests of another class of persons where this would impose on them conflicting claims or obligations. ${ }^{76}$ Here a conflict would have arisen between the functions carried out by the child welfare authority, including investigating and reporting on possible child abuse, and a duty of care to those accused of that very thing. ${ }^{77}$

In Graham Barclay Oysters Pty Ltd v Ryan ${ }^{78}$ consumers who had suffered illhealth after eating contaminated oysters alleged negligence against the local authority and state government with responsibilities over the waters from which the oysters had been harvested. The Court dismissed the claim. In so doing, it made several observations of significance to the discussion in

\footnotetext{
${ }^{75}$ See also Crimmins v Stevedoring Industry Finance Committee (1999) 200 CLR 1, 77 (Kirby J), 102-3 (Hayne J).

${ }^{76}$ Sullivan v Moody (2001) 207 CLR 562,582 (Gleeson CJ, Gaudron, McHugh, Hayne and Callinan JJ). The Court also expressed concern with possible indeterminate liability (582) and noted that the plaintiffs might have remedies under the existing law of defamation (581).

${ }^{77}$ Ibid 582.

${ }^{78}$ (2002) 211 CLR 540.
} 
McKenna. McHugh J acknowledged that the mere fact that a public authority was conferred with powers the exercise of which could prevent harm to others did not mean that the authority owed a duty of care. However McHugh J then cited situations where such an authority would ordinarily owe a duty of care. These were where (a) the authority has used its powers to intervene in a field of activity and thereby increased the risk of harm to persons; or (b) it knew or ought to have known that a member of the public relies on it to exercise a power to protect that person's interests. ${ }^{79}$ While the first requirement is not satisfied in the instant McKenna case, the second is.

McHugh $\mathrm{J}$ further identified several matters to be considered in relation to whether a statutory authority owes a duty of care. It is necessary to ask whether:

a reasonable public authority would reasonably foresee that its act or omission, including a failure to exercise its statutory powers, might result in injury to the plaintiff or the plaintiff's interests;

the authority was in a position of control and whether it had any power to control the situation that brought about the harm to the injured person ;

either the injured person or their interests were vulnerable in the sense that the injured person could not reasonably be expected to adequately safeguard him- or herself from harm;

the public authority knew, or ought it to have known, of an existing risk of harm to the plaintiff or a specified class of persons including the plaintiff;

the imposition of the duty of care on the authority would make it liable with respect to the defendant's exercise of core policy-making or quasi-legislative functions. ${ }^{80}$

In McKenna all questions except the last can be answered affirmatively.

Gummow and Hayne JJ also alluded to the relevance of the degree and nature of control exercised by the authority over the harm that eventuated, the degree of vulnerability of those depending on the proper exercise by the authority of the powers, and whether the suggested duty was consistent with the terms,

\footnotetext{
${ }^{79}$ Ibid 576.

${ }^{80}$ Ibid 577.
} 
scope and purpose of the relevant statute ${ }^{81}$ In denying that a duty existed in the Graham Barclay Oysters case, Gummow and Hayne JJ took into account that the state was not aware of any particular contamination risk, and there had been no prior outbreaks. ${ }^{82}$

The High Court also considered the liability of public authorities in Brodie $v$ Singleton Shire Council. ${ }^{83}$ There, Gaudron, McHugh and Gummow JJ noted that the statutory powers given to public authorities may give it such a significant and special measure of control over safety and property as to impose a duty of care. The duty might entail seeking to minimise a danger to safety or to warn of the danger, but control was a paramount issue. ${ }^{84}$ The duty of care was owed to a class of persons, identified as users of roads within the local authority's control. ${ }^{85}$ The joint reasons noted that 'the formulation of the duty of care includes consideration of competing or conflicting responsibilities of the authority' ${ }^{86}$ It should be noted that the existence of competing or conflicting responsibilities did not negate a duty of care; rather, such facts would help shape, and confine, the posited duty of care.

In Pyrenees Shire Council $v$ Day ${ }^{87}$ the court found no conflict between the Council's responsibilities under the Local Government Act 1958 (Vic), and a common law duty to those living in the immediate area of the relevant premises. The Council had exercised its statutory power to inspect a fireplace, and had deemed the fireplace in the premises to be unsafe. It wrote to the occupying tenant to that effect, warning that the fireplace should not be used until repairs were made. The tenant did not pass the letter on to the owner, or inform the owner of the contents. The Council did not follow the matter up to ensure that the necessary repairs had been made. New tenants subsequently moved in and two years later the premises and adjoining premises were destroyed by a fire caused by the defects in the fireplace.

\footnotetext{
${ }^{81}$ Ibid 597-8; to like effect Kirby J (617); Callinan J spoke of 'vulnerability, power, control, generality or particularity of the class, resources of and demands upon the authority' (664); Gleeson CJ stated that a general legislative power to protect the public did not ordinarily give rise to a duty of care to a particular individual or members of a particular class (562).

82 Ibid 607.

83 (2001) 206 CLR 512.

${ }^{84}$ Ibid 559.

${ }^{85}$ Ibid 577.

${ }^{86}$ Ibid 580-1.

${ }^{87}$ (1998) 192 CLR 330.
} 
At least one of the reasons why the Council had been given power with respect to fireplaces was to reduce the risk of harm to nearby residents. ${ }^{88}$ The plaintiff (one of the neighbours) was within a class of claimants within the contemplation of the legislation. ${ }^{89}$ The risk involved in not complying with the inspector's directions was extreme. ${ }^{90}$ Neighbours were vulnerable and relied on the Council to exercise its powers appropriately and protect them from harm. ${ }^{91}$

Earlier, in Sutherland Shire Council $v$ Heyman, ${ }^{92}$ Gibbs CJ stated that ordinary principles of the law of negligence should apply to public authorities, and that they could be liable, if they exercised a power negligently, to someone who relied on what the public authority did and could show injury suffered as a result of the negligence. ${ }^{93}$ Mason J agreed that a public authority could owe a duty of care to others, expressing this principle in terms of that authority 'creating a danger' ${ }^{94}$ In that context the authority could owe a duty of care to preserve the safety of others. Alternatively the negligence of public authorities could be based on the reliance of the injured party on the exercise of the duty of care. ${ }^{95}$

The possible application of the principles derived from these cases to the facts at issue in the recent McKenna decision will be considered later in this article.

\section{A Non-High Court Decisions}

\section{$1 \quad$ United Kingdom}

A case with equivalent facts to those of the McKenna decision is Home Office $v$ Dorset Yacht Co Ltd. ${ }^{96}$ There young detainees in an institution for at-risk youth escaped from an island. The detainees had criminal records, and had

\footnotetext{
${ }^{88}$ Ibid 342 (Brennan CJ).

${ }^{89}$ Ibid 347 (Brennan CJ).

${ }^{90}$ Ibid 348 (Brennan CJ).

${ }^{91}$ Ibid 359 (Toohey J), 370 (McHugh J).

92 (1985) 157 CLR 424.

${ }^{93}$ Ibid 445; to like effect Crimmins v Stevedoring Industry Finance Committee (1999) 200 CLR 1, 29 (McHugh J regarded as a 'settled category' 'that when statutory powers are conferred they must be exercised with reasonable care, so that if those who exercise them could by reasonable precaution have prevented an injury which has been occasioned, and was likely to be occasioned, by their exercise, damages for negligence may be recovered'.

${ }^{94}$ Ibid 460.

${ }^{95}$ Ibid 461, 464.

${ }^{96}$ [1970] AC 1004.
} 
escaped from institutions in the past. They were not properly restrained or supervised by relevant officers. There was a deliberate government policy of giving those detained as much freedom and responsibility as possible, with a view to developing trust and responsible decision making. In the course of their escape, a boat 'borrowed' by the detainees collided with a yacht owed by the plaintiff, and then boarded it, causing further damage to it. The owner of the yacht sued the administrator of the institution in negligence. Four of five members of the House of Lords dismissed an appeal against a finding that the Home Office owed a duty of care to the yacht owner.

Lord Reid stated that there was good authority to support an action against a public authority that had exercised a statutory duty negligently. ${ }^{97} \mathrm{He}$ distinguished cases involving an exercise of discretion, but found that, if the discretion was exercised carelessly or unreasonably, an action might still lie. He acknowledged that the Home Office had conflicting considerations with which to contend - the public interest in protecting neighbours and their property from escapees, as opposed to the public interest in promoting rehabilitation..$^{98}$ It had pursued a policy of maximising detainees' freedom with rehabilitation in mind. This was reflected in statutory rules. ${ }^{99}$ Importantly, the fact that these conflicting considerations existed did not lead Lord Reid to a finding that to impose a duty of care on the Home Office with respect to an owner of a yacht nearby would be inconsistent with their duties to detainees. Similarly Lord Morris acknowledged that officers had duties of care to their employers. This did not obviate a duty of care to detainees; rather he held that the common law duty of care to detainees would be 'conditioned by' the other duties. ${ }^{100}$ Lord Morris emphasised the control that the officers had over those detained, in establishing that a duty of care towards the detainees existed. ${ }^{101}$ Lord Pearson took a similar view. After acknowledging the Home Office's deliberate policy of light supervision of, and freedom for, those detained in youth detention facilities, his Lordship continued:

it would affect only the content or standard and not the existence of the duty of care. It may be that when the method is being intensively employed there is not very much that the Defendants' officers can do for the protection of

\footnotetext{
${ }^{97}$ Ibid 1031.

98 Ibid.

99 Borstal (No 2) Rules, 1949, r 25 referred to every inmate being able 'to develop his individuality on right lines and with a proper sense of personal responsibility. Officers shall therefore, while firmly maintaining discipline and order, seek to do so by influencing the inmates by their own example and leadership and by enlisting their willing co-operation'.

${ }^{100}$ Home Office v Dorset Yacht Co Ltd [1970] AC 1004, 1036.

${ }^{101}$ Ibid 1039.
} 
the neighbours and their property. But it does not follow that they have no duty to do anything at all for this purpose. They should exercise such care for the protection of the neighbours and their property as is consistent with the due carrying out of the Borstal system of training. ${ }^{102}$

Lord Diplock referred to the reconciliation of competing interests in accepting the existence of a duty of care in the case. ${ }^{103}$ This balance of competing interests is also a theme in the Court of Appeal decision in W $v$ Egdell, ${ }^{104}$ where Bingham LJ discussed the balance between a mental health patient's legitimate desire to regain freedom, and the public's legitimate desire to be protected from violence. President Brown (as he then was) discussed exceptions to the general rule in favour of patient confidentiality, finding that an exception was justified in the interests of public safety. ${ }^{105} \mathrm{~A}$ claim such as this is less likely to be successful when the victim is not identified or identifiable as a member of a specific class. ${ }^{106}$

More common have been claims against police authorities. These cases present facts analogous to those in McKenna to the extent that they involve questions about the exercise, or non-exercise, of statutory functions in the context of a victim complaining of injuries suffered as a result of the manner

102 Ibid 1056.

103 Ibid 1068-9: 'this ... is the way in which the courts should set about the task of reconciling the public interest in maintaining the freedom of the Home Office to decide upon the system of custody and control of Borstal trainees which is most likely to conduct to their reformation and the prevention of crime and the public interest that Borstal officers should not be allowed to be completely disregardful of the interests both of the trainees in their charge and of persons likely to be injured by their carelessness without the law providing redress to those who in fact sustain injury'. It should be acknowledged that Lord Diplock stated in dicta that a decision to deliberately release a detainee which led to injury to a plaintiff would not lead to liability on the part of the Home Office, unless the decision was a wholly unreasonable one (1068). The House of Lords would later abandon the 'wholly unreasonable' test for establishing whether or not a public authority was liable in negligence: $X$ (Minors) $v$ Bedfordshire County Council [1995] 2 AC 633, 736 (Lord Browne-Wilkinson, for the House).

104 [1990] 1 Ch 359.

105 See also Jones $v$ Smith [1999] 1 SCR 455 (where a solicitor-client privilege was waived with respect to a psychiatric report which suggested that a particular person was likely to kidnap, rape and murder prostitutes in future — due to an overriding public safety interest in that waiver).

106 Palmer v Tees Health Authority [2000] PNLR 87 (Stuart-Smith, Pill, Thorpe LJJ). (In this case a person had come to the attention of the Authority as someone suffering from a personality disorder and psychopathic personality. The person, who had been detained for a period in the hospital but had been released, had some history of violence and had suffered sexual abuse as a child. He subsequently raped and murdered a four year old girl. The girl's mother's claim for psychiatric injury was rejected as disclosing no cause of action, because the plaintiff was not a member of an identified or identifiable class). 
in which those functions were carried out. There is evident reluctance to find police authorities liable in negligence for failing to prevent crime being committed, even where the victim had brought the specific danger to the attention of police. ${ }^{107}$ In these cases, the courts have established a general rule that police do not owe a duty of care to victims of crime to prevent crime from occurring. This is subject to exceptions, including where there is control for instance over the person who causes injuries to another - or an assumption of responsibility - for example in relation to a person, or, perhaps, a situation. A duty of care has been found to be owed by the police where a person was detained involuntarily in police custody. ${ }^{108}$ More commonly, claims against police in negligence have been dismissed. ${ }^{109}$

Despite this, the cases are of some use here. Their reasoning is at some points similar to the reasoning that led the High Court to deny that a duty of care was owed in McKenna. The similarity lies in the focus on the practical difficulties caused by the imposition of a duty of care on the relevant decision maker. For instance, a duty of care would encourage the decision maker to adopt a 'detrimentally defensive frame of mind' 110 and would have financial implications for the government ${ }^{111}$ which would need to defend such actions and also take pro-active measures to minimise the risk of liability. Furthermore, it can be argued that the courts are not equipped to effectively second-guess police decisions regarding lines of enquiry. ${ }^{112}$ These arguments will be further considered below. Further, in the recent case of Michael $v$ Chief Constable of South Wales Police, ${ }^{113}$ the two dissenting justices made statements supportive of the position taken in this article:

the time has come to recognise the legal duty of the police force to take action to protect a particular individual whose life or safety is, to the knowledge of the police, threatened by someone whose actions the police are able to restrain. ${ }^{114}$

\footnotetext{
${ }^{107}$ Michael $v$ Chief Constable of South Wales Police [2015] 2 WLR 343.

${ }^{108}$ Kirkham v Chief Constable of the Greater Manchester Police [1990] 2 QB 283, 289. .

${ }^{109}$ Michael v Chief Constable of South Wales Police [2015] 2 WLR 343, and the cases cited therein.

${ }^{110}$ Van Colle v Chief Constable of the Hertfordshire Police [2008] 3 WLR 593, 624 [89] (Lord Phillips), 632-3 [132] (Lord Brown).

${ }^{111}$ Michael $v$ Chief Constable of South Wales Police [2015] 2 WLR 343, 371 [122] (Lord Toulson, with whom Lord Neuberger, Lord Mance, Lord Reed and Lord Hodge agreed).

${ }^{112}$ Hill v Chief Constable of West Yorkshire [1989] 1 AC 53.

113 [2015] 2 WLR 343.

${ }^{114}$ Ibid 385 [175] (Lord Kerr), with whom Lady Hale expressed agreement: 390-1 [197].
} 


\section{$2 \quad$ United States}

The Supreme Court of California considered analogous questions in Vitaly Tarasoff $v$ Regents of the University of California. ${ }^{115}$ There Prosenjit Poddar apparently told a University psychologist of his plans to kill the victim, Tatiana Tarasoff, who had spurned his advances. Police briefly detained Poddar, but he was then released. No one informed the victim, or her family, of the threat. Two months later, Poddar killed the victim. Her family brought action in negligence against the employer of the psychologist and the police for failure to protect and failure to warn Tarasoff. In a landmark decision the Supreme Court found that a claim against the psychologist should proceed.

The Court expressly held that the legal responsibilities of the psychologist were not confined to the immediate patient, but extended at least to those whom the psychologist knew were threatened by the patient. ${ }^{116}$ The Court considered and rejected claims that to impose a duty of care on the psychologist to others would be inconsistent with the duty of care, including a duty of confidentiality, that the psychologist owed to the patient, and that free and open communication was essential to the practice of psychology, something which recognition of a duty of care to third parties would inhibit. The Court responded that this interest had to be weighed against the public interest in safety from violence, ${ }^{117}$ concluding that 'the protective privilege ends where the public peril begins'. ${ }^{118}$

In Lipari $v$ Sears, Roebuck \& Co, ${ }^{119}$ the offender had been involuntarily detained in a mental hospital run by the Veterans Administration, a United States agency. He was released and placed on a voluntary treatment program, which he subsequently discontinued. A month later he shot and killed one person and seriously injured another. The Court found that the United States agency owed a duty of care to third parties in relation to the offender. The Nebraskan Court specifically rejected the argument accepted by the High Court in McKenna:

A second policy argument raised by the United States involves the goal of placing mental patients in the least restrictive environment. The United States contends that imposing liability on a psychotherapist would conflict with this goal because therapists would attempt to protect themselves from liability by placing their patients in a restrictive environment. This argument

\footnotetext{
115551 P 2d 334 (Cal, 1976).

${ }^{116}$ Ibid 344.

117 Ibid 346.

${ }^{118}$ Ibid 347.

119497 F Supp 185 (D Neb, 1980).
} 
misinterprets the nature of the duty imposed upon the therapist. The recognition of this duty does not make the psychotherapist liable for any harm caused by his patient, but rather makes him liable only when his negligent treatment of the patient caused the injury in question ... despite the defendant's protests to the contrary, a psychotherapist is not subject to liability for placing his patient in a less restrictive environment, so long as he uses due care in assessing the risks of such a placement. ${ }^{120}$

Other American courts have noted the potential for conflict between goals of rehabilitation and treatment on the one hand, and public safety on the other. Notably, this has not led to a denial that those in charge of mental health facilities, prisons, and other public facilities and institutions, owe or may owe a duty of care to members of the general public. It might, however, mean that a duty of care (in the sense of a duty to warn, rather than a duty to protect) is more likely to be recognised where the specific dangerousness of the person released sets this person apart from the typical detainee. ${ }^{121}$ Further, liability might be limited to members of an identifiable class, if such is possible, rather than to the general public. A family member of the person attacked has been recognised as belonging to an identifiable class. ${ }^{122}$ Some courts have permitted claims although no class narrower than the general public is readily identifiable. ${ }^{123}$

The Supreme Court of Ohio decision of Estates of Morgan v Fairfield Family Counselling Center ${ }^{124}$ involved facts similar to those of McKenna. Morgan had been diagnosed with schizophrenia and psychosis. He was being treated by the defendant with psychotherapy and counselling, and had been for several months. He began not taking his medication, and his parents noticed that his behaviour was deteriorating, evidenced by increasing verbal abuse, apparent conversations with someone who was not there, and complaints of physical assaults and pain that were not real. Morgan was assessed twice with a view to involuntary detention, and on both occasions it was determined that

\footnotetext{
${ }^{120}$ Ibid 188-93; adopted and applied in Durflinger v Artiles 727 F 2d 888, 901-6 $\left(10^{\text {th }}\right.$ Cir, 1984).

${ }^{121}$ Rollins $v$ Petersen 813 P 2d 1156, 1161 (Utah, 1991): 'The sensible approach is to recognize a duty on the part of the custodian that does not discourage the operation of transitional programs, but requires the custodian to use special care when the one in custody sets him- or herself apart ... in terms of dangerousness to an identifiable person or persons'.

${ }^{122}$ Hedlund $v$ The Superior Court of Orange County 669 P 2d 41 (Cal, 1983) (a case of a son who suffered a psychiatric injury after a patient being treated by psychologists shot his mother in the presence of the son).

${ }^{123}$ Estate of Johnson by Johnson v Village of Libertyville 496 NE 2d 1219, 1223 (Ill App 2 Dist, 1986).

${ }^{124} 673$ NE 2d 1311 (Ohio, 1997).
} 
he did not fit the criteria. Six weeks after the last assessment, he shot and killed his parents and injured his sister.

The Supreme Court accepted that the defendant owed a duty of care to the plaintiffs. It reasoned that many cases involved the striking of a balance between countervailing public interests, including a patient's interest in being placed in the least restrictive environment possible and in not being involuntarily detained. ${ }^{125}$ The Court admitted to

some trepidation concerning the imposition of a duty because of the fear that therapists will attempt to protect themselves from liability by involuntarily hospitalizing nonviolent mental patients... This fear, however, has no reliable statistical support. ${ }^{126}$... Instead, the statistical evidence that is available indicates that Tarasoff has not discouraged therapists from treating dangerous patients, nor has it led to an increased use of involuntary commitment of patients perceived as dangerous. ${ }^{127}$

This reasoning partly answers concerns raised in the police liability context in the United Kingdom regarding whether recognition of a duty of care would cause the decision maker to adopt a 'detrimentally defensive' frame of mind, as assumed by the House of Lords in Hill. The research cited in the passage above casts doubt on the extent to which recognition of a duty of care by the

\footnotetext{
125 Ibid 1321.

126 The judges cited Daniel J Givelber, William J Bowers and Carolyn L Blitch, 'Tarasoff, Myth and Reality: An Empirical Study of Private Law in Action' [1984] Wisconsin Law Review 443, 486. A similar result is found in Paul S Appelbaum, 'The New Preventive Detention: Psychiatry's Problematic Responsibility for the Control of Violence' (1988) 145 American Journal of Psychiatry 779. Fox concluded that the effects of a duty to warn on the psychotherapist-client relationship had been minimal: Patrick Fox, 'Commentary: So the Pendulum Swings - Making Sense of the Duty to Protect' (2010) 38(4) Journal of the American Academy of Psychiatry and the Law 474, 475, as did Mossman, 'Critique of Pure Risk Assessment Or, Kant Meets Tarasoff' (2006) 75 University of Cincinnati Law Review 523, 526: 'Psychotherapists accept the fact that, while they may regard themselves as the caregivers of individual patients, they sometimes must function as agents for social protection' and as did Renée L Binder and Dale E McNiel, 'Application of the Tarasoff Ruling and its Effect on the Victim and the Therapeutic Relationship' (1996) 47(11) Psychiatric Services 1212. Wise commented on the positive social effects of the Tarasoff decision: 'to the extent that Tarasoff has encouraged therapists to probe more fully into potential violence and to consult with colleagues when they confront it, the decision may be a boon to the proper identification of the dangerous patient': Toni Wise, 'Where the Public Peril Begins: A Survey of Psychotherapists to Determine the Effects of Tarasoff' (1978) 31(1) Stanford Law Review 165, 186.

127 Estates of Morgan v Fairfield Family Counselling Center 673 NE 2d 1311, 1325 (Ohio, 1997).
} 
mental health professional in cases such as McKenna would lead to the kind of change in behaviour feared by some justices. ${ }^{128}$

Fears that the Tarasoff decision would lead to an unsustainable increase in successful claims against mental health professionals for breaching the duty of care have similarly not been supported by empirical evidence. A study of more than 100 claims at appellate level against mental health professionals for failure to protect or failure to warn concluded that

defendants are now rarely held to be negligent on grounds of failing to warn or protect. In reviewing 21 years of legal history, we found just four cases in which psychotherapists were found liable for breach of a Tarasoff duty. ${ }^{129}$

Fears that the recognition of a duty of care to third parties was inconsistent with the mental health professional's duty of care to the patient were also negated by comments such as the following from a practising psychiatrist and scholar that 'I can scarcely conceive of a psychiatric interview in which the patient's risk to self or others is not addressed'. ${ }^{130}$ An empirical study among mental health professionals found that 'a duty to protect potential victims is not viewed as ethically repugnant'. ${ }^{131}$

While the general words of the Restatement (Second) of Torts ${ }^{132}$ had been interpreted consistently with the Tarasoff decision to impose a duty on the mental health professional, the Restatement $\left(3^{r d}\right)$ of Torts is even more explicit. Section 41(b)(4) specifically recognises a duty of a mental health

\footnotetext{
${ }^{128}$ Peterson has concluded that concerns about defensive decision making in the current context 'show a concerning scepticism about the integrity of medical decision-making': Kathryn Peterson, 'Where is the Line to be Drawn? Medical Negligence and Insanity in Hunter Area Health Service v Presland' (2006) 28 Sydney Law Review 181, 187.

129 Matthew Soulier, Andrea Maislen and James Beck, 'Status of the Psychiatric Duty to Protect, Circa 2006' (2010) 38(4) Journal of the American Academy of Psychiatry and the Law 457, 469.

${ }^{130}$ Fox, above n 126, 475.

${ }^{131}$ Givelber, Bowers and Blitch, above n 126, 486, and 'our respondents only endorsed the broader principle that a therapist has ethical responsibilities to protect potential victims ... the data certainly contradict the assertion that therapists must only concern themselves with the welfare of their patients and not with that of society at large' (476). Recently Hafemeister, McLaughlin and Smith stated that it was now widely acknowledged that the effect of the Tarasoff ruling had not been 'ruinous' to clinical practice: Thomas Hafemeister, Leah McLaughlin and Jessica Smith, 'Parity at a Price: The Emerging Professional Liability of Mental Health Providers' (2013) 50(1) San Diego Law Review 29, 79.

${ }^{132}$ American Law Institute, Restatement (Second) of Torts (1965).
} 
professional to third parties who might be harmed by the actions of their patient. ${ }^{133}$

In summary, the American decisions demonstrate that the release of a person from care is not inconsistent with obligations owed by mental health professionals to recognise that they might owe a duty of care to those placed at risk by a decision. This has not caused major disruption to the way in which mental health professionals do their work. Release of a person from care was not, and is not, inconsistent with their practice, and does not raise serious ethical issues. Further, the 'sky has not fallen in' in the sense that no unmanageable number of claims, or successful claims, have been made against mental health professionals for the release of detainees. While there is no suggestion that American law should provide the basis for the law in Australia, these cases are relevant to any assessment of the reasoning utilised by the High Court to deny that a duty of care existed in McKenna. They do not provide support for an argument that the recognition of a duty of care in the field of mental health care would create inconsistency of obligations, or open a floodgate to litigation.

Further, the equivalent ${ }^{134}$ English authorities have been even more prepared than their US counterparts to find that a duty of care exists where there has been an assumption of responsibility, and control. Specifically, despite general reluctance to find that police owe a duty of care, such a duty has been established where police have involuntarily detained an individual, and detained that person in police custody. The grounds for this finding are the police's control over, and assumption of responsibility for, that individual.

\section{Why the High COURT Was WRONg to Deny that a DUTY OF CARE EXISTED IN THE CIRCUMSTANCES}

Having considered past Australian and overseas precedent on the question of duties of care owed by public authorities in relevant contexts, in the final part of this article the reasoning utilised by the High Court to deny a duty of care in McKenna will be considered. It is the present author's view that the High

\footnotetext{
${ }^{133}$ American Law Institute, Restatement (Third) of Torts: Liability for Physical and Emotional Harm (2010). It should be acknowledged that some states have moved to regulate by statute the liability of mental health professionals. See for discussion Michael Geske, 'Statutes Limiting Mental Health Professionals’ Liability for the Violent Acts of Their Patients' (1999) 64(2) Indiana Law Journal 391.

134 They are equivalent in the sense that the power of involuntary detention was utilised. Suspected criminals are not being equated to those suffering from mental illness.
} 
Court was wrong to deny that a mental health authority could, or did, owe a duty of care to family members of a person killed by someone whom the mental health authority had just released. This denial was largely due to the Court's finding of an inconsistency or incompatibility between the duty said to arise, and other provisions of the mental health legislation at the relevant time. Most particularly the Court took into account the prevailing clear policy that involuntary detention was to be a last resort, and that treatment should be minimally invasive of the patient's dignity and human rights. The errors of the High Court's view will now be explained. Issues that, although relevant to the resolution of the dispute, did not form part of the High Court's reasoning in the case, will not be considered. ${ }^{135}$

\section{A The Act}

Authorities such as Sullivan $v$ Moody and Pyrenees Shire Council v Day indicate that the object, scope and terms of the relevant statute are important considerations in deciding whether a statutory authority owes a common law duty of care to others with respect to the exercise of its powers. ${ }^{136}$

It is true, as the High Court pointed out in McKenna, that sections of the Mental Health Act 1990 (NSW) ${ }^{137}$ clearly focused on the treatment of individuals suffering from mental illness. They demonstrated appropriate sensitivity to the impact that involuntary detention and treatment might have on individuals by requiring that the least invasive means of treatment be used. ${ }^{138}$ However, this discussion by the High Court was highly selective. The Court did not discuss section 21 which allowed a medical practitioner or authorised person to detain a person based on an opinion that the person was suffering from a mental illness or disorder. Chapter 3 of the legislation was entitled 'Mentally Ill and Mentally Disordered Persons'. Section 8, in that chapter, stated that for the purposes of assessing whether a person should be involuntarily detained under the Act, a person was mentally ill or disordered only if the person met the criteria set out in that Chapter. Relevantly, section 9 stated that a person was mentally ill if the person was suffering from a mental illness and, owing to that illness, there were reasonable grounds for believing that care, treatment and control of the person was necessary:

\footnotetext{
135 These include, for example, the fact that it was a claim for psychiatric injury, the question of whether any posited duty of care was breached, and the question of causation.

${ }^{136}$ For example, Graham Barclay Oysters Pty Ltd v Ryan (2002) 211 CLR 540, 563 (Gleeson CJ), 574 (McHugh J), 597-8 (Gummow and Hayne JJ) (with whom Gaudron J agreed (570)), 617 (Kirby J), 658-9 (Callinan J).

${ }^{137}$ Now repealed.

${ }^{138}$ For instance, Mental Health Act 1990 (NSW) ss 4, 20, 28, $29,35$.
} 
(i) for the person's own protection from serious harm; or

(ii) for the protection of others from harm (emphasis added).

Section 10 stated that a person was a mentally disordered person if the person's behaviour at a given time was so irrational as to justify a conclusion on reasonable grounds that temporary care, treatment or control of the person was necessary:

(i) for the person's own protection from serious harm; or

(ii) for the protection of others from harm (emphasis added). ${ }^{139}$

Thus, of the two criteria that a medical practitioner was to consider in assessing whether a person was suffering from a mental illness or mental disorder (concepts relevant to whether a person is to be involuntarily detained), one of them required the decision maker to have regard to whether care, treatment and control of the person was necessary to protect others from harm.

Given this fact, it is very difficult to fathom, or accept, the (relatively terse) finding of the High Court in McKenna ${ }^{140}$ that to accept that decision makers in such cases have a duty of care to possible victims of a person they might release would be inconsistent with the mental health legislation under which the decision to detain or release is made. ${ }^{141}$ With respect, how can it be inconsistent when the Act itself expressly contemplates - indeed requires that the decision maker will take into account the risk to others in assessing

\footnotetext{
139 Sections 14 and 15 of the (current) Mental Health Act 2007 (NSW) are in materially similar form, again including 'protection of others from harm' as one of the two criteria to be considered. This mirrors mental health legislation elsewhere: see Mental Health Act 2014 (Vic) s 29(b)(ii); Mental Health Act 2000 (Qld) s 13(1)(d)(i); Mental Health Act 2009 (SA) s 21(1)(b); Mental Health Act 2006 (WA) s 26(1)(b)(i); Mental Health Act 2013 (Tas) s 17(1)(c); Mental Health (Treatment and Care) Act 1994 (ACT) s 26(p)(ii); Mental Health and Related Services Act 1998 (NT) s 14(A).

${ }^{140}$ The Court explained its findings regarding inconsistent duties in five paragraphs: (2014) 253 CLR 270, 281-2, [29]-[33].

${ }^{141}$ In this sense, the case is more akin to the finding in Pyrenees Shire Council v Day (1998) 192 CLR 330 that although the Council owed obligations to a range of individuals, the obligation to a particular home owner complemented, and was not mutually exclusive of, obligations to owners of neighbouring properties, because the overriding obligation was public safety. The same can be said in this case. Therefore Sullivan v Moody (2001) 207 CLR 562 can be distinguished because in that instance there really could be a conflict between a duty to thoroughly investigate claims of child abuse, guided by the best interests of the child, and the right of a person under investigation to his or her reputation.
} 
whether a person is mentally ill or mentally disordered, concepts directly linked to questions of involuntary detention? ${ }^{142}$

It is also worth recalling Hunter Area Health Service $v$ Presland, ${ }^{143}$ coincidentally a very similar case of negligence brought against a mental health service in that region. There the plaintiff had been taken by police to a hospital following 'bizarre and violent' behaviour involving telling a person 'he didn't think he could kill him', hitting a victim with a fence paling, grabbing others (including a three year old child) by the throat, jumping up into the air, and claiming that the 'rats must die'. He was then transferred to a public psychiatric hospital for assessment. That hospital released him on the same day, in the company of his brother. Six hours later the plaintiff killed his brother's fiancé. He was acquitted of a charge of murder on the basis of mental illness, and was committed to a psychiatric institution. When released, he sued the mental health authority, arguing that it was negligent in releasing him so soon on the first occasion. He claimed that, if the authority had not done so, he would not have killed the victim and been subsequently involuntarily detained, which he claimed caused him emotional distress.

A majority of the New South Wales Court of Appeal rejected the plaintiff's negligence claim. Notwithstanding this, comments made in the judgment are highly relevant here. Spigelman CJ, dissenting in the result, noted the existence of sections 9 and 10 of the ..., including the reference to protection of others from harm. He considered this an important criterion to be used in determining the need for detention. His Honour noted:

If this were proceedings by a third party who had suffered harm at the hands of a mentally ill or disordered person, then it would fall within the intended sphere of protection to which the statutory provisions expressly relate. ${ }^{144}$ (emphasis added)

\footnotetext{
${ }^{142}$ To reiterate, the purpose of determining whether a person is suffering from a mental illness or mental disorder is to consider their involuntary detention, continued involuntary detention or community treatment order: Mental Health Act 1990 (NSW) s 8.

143 [2005] NSWCA 33. See for discussion Ian Freckelton, 'Liability of Psychiatrists for Failure to Certify: Presland v Hunter Area Health Service and Dr Nazarian' [2003] NSWSC 754' (2003) 10(2) Psychiatry, Psychology and Law 397; Kathryn Peterson, 'Where is the Line to be Drawn? Medical Negligence and Insanity in Hunter Area Health Service $v$ Presland' (2006) 28 Sydney Law Review 181.

144 Presland [2005] NSWCA 33 [29]. A leading scholar in the medico-legal field agrees: 'Properly construed ... the criteria for involuntariness are not in conflict with the recognition of a duty to treat provided the criteria are satisfied': Ian Freckelton, 'Legal Liability for Psychiatrists' Decisions about Involuntary Inpatient Status for Mental Health Patients' (2014) 22 Journal of Law and Medicine 280, 288.
} 
These comments are dicta, but they fit the situation at issue in McKenna. If Spigelman CJ had been considering that case, he surely would have found the existence of a duty of care owed to the plaintiffs, based on these comments. ${ }^{145}$ His conclusion (based on the same provisions as those considered in McKenna) is diametrically opposed to the interpretation rendered by the High Court in that case. With respect, the view of Spigelman CJ is much to be preferred, based on the clear wording of the sections - sections 9 and $10-$ to which the High Court did not refer in McKenna.

Further, while Spigelman CJ was dissenting in Presland, one member of the majority, Santow JA, stated that, although he rejected this claim, he might have reached a different conclusion had the plaintiff been someone who suffered at the hand of a person negligently released from a mental health unit. ${ }^{146}$ This was in the context of his statement that any person or organisation claiming immunity from general principles of negligence liability, including statutory authorities, had to satisfy a 'heavy burden of justification', ${ }^{147}$ and his agreement with Spigelman CJ's espousal of relevant principles in terms of liability in negligence of statutory authorities. ${ }^{148}$ This suggests to the author that, on facts such as those in McKenna, Santow JA is likely to have reached the same conclusion as Spigelman CJ did in dissent in Presland.

Another decision, from South Australia, found that a parole authority owed a duty of care to the victims of a person whom it had released early upon conditions. The duty arose based on specific information proven to have been known to the authorities (presumably from public complaints) that the person released was in breach of his parole conditions, placing children at risk. The court did not conclude in that case that a duty of care to these victims was

\footnotetext{
${ }^{145}$ Spigelman CJ dismissed an argument that a finding that a duty of care was owed to those other than the patient would lead to the practice of defensive medicine: 'The Court ought to be slow to conclude that a medical practitioner acting true to his or her profession, would permit the process of formulating a professional opinion be distorted by the prospect of civil liability': Presland [2005] NSWCA 33 [37]. In contrast Sheller JA was concerned that this might occur: at [297].

146 'This is not the case of an action brought by a third party against a careless hospital who was physically injured during a psychotic episode at the hands of someone whose compulsory detention for treatment would have averted the injury to that person': ibid [345]. Certainly, the fact that in Presland it was the wrongdoer who was the one claiming compensation was relevant to the court's decision to reject the claim.

${ }^{147}$ Ibid [345].

${ }^{148}$ Ibid [325].
} 
inconsistent with the parole board's duties to rehabilitate offenders through the prudent use of early parole. ${ }^{149}$

Similarly, the United Kingdom decision of Home Office $v$ Dorset Yacht Co Ltd and American decisions such as Tarasoff, raise questions about the extent to which duties of care to those detained involuntarily do irreconcilably conflict with duties to those who might be injured by someone being released from care. In Home Office, the Court clearly concluded that the recognition that authorities owed a duty of care to those who might be affected by escaped residents did not conflict with the policy of the facility to provide maximum freedom to residents and allow them to make decisions as much as possible. The American decisions, led by Tarasoff, tend to negate the suggestion of an impossible conflict between the duty owed by mental health professionals to their patients, including their duty to use minimally invasive treatment, and the duty of care owed to those who might be injured by the person released from involuntary detention. In fact, such duties have happily co-existed in the United States for some years. The evidence is that such co-existence has not proven to be impossible, has not really changed the way in which mental health practice has functioned, and is not inconsistent with the ethical obligations owed by such professionals. Rates of litigation against mental health professionals have not proven unmanageable. As always, there is no substitute for evidence-based decision making in preference to generalisations, or assumptions that recognising mental health professionals as owing a duty of care to members of the general public will lead to unmanageable litigation levels.

\section{B Criteria for Recognition of a Duty of Care Owed by Public Authorities}

In Crimmins McHugh $\mathrm{J}_{\text {listed }}{ }^{150}$ five factors to be considered in deciding whether a public authority owes a duty of care:

(1) whether a reasonable public authority would reasonably foresee that its act or omission, including failure to exercise powers, might result in injury to the plaintiff;

(2) whether the public authority was in a position of control; ${ }^{151}$

\footnotetext{
149 Swan v State of South Australia (1994) 62 SASR 532 (Bollen J, with whom Mohr and Duggan JJ agreed).

150 Crimmins v Stevedoring Industry Finance Committee (1999) 200 CLR 1, 39; Graham Barclay Oysters Pty Ltd v Ryan (2002) 211 CLR 540, 577.
} 
(3) whether the plaintiff/s were vulnerable in that they could not reasonably be expected to adequately protect themselves from harm; ${ }^{152}$

(4) whether the public authority knew, or ought to have known, of an existing risk of harm to the plaintiff or of a class of persons of whom the plaintiff was one; ${ }^{153}$ and,

(5) whether the imposition of the duty would impose liability with respect to the defendant's core policy making or quasi-legislative functions.

Each of these factors will now be applied to the facts in McKenna. ${ }^{154}$

151 Control was also cited as a critical consideration, in the context of whether a statutory authority owed a duty of care, by Gummow and Hayne JJ in Graham Barclay Oysters Pty Ltd $v$ Ryan (2002) 211 CLR 540, 597 (with whom Gaudron J agreed (570)), Kirby J (630), Callinan J (664); and in Stuart v Kirkland-Veenstra (2009) 237 CLR 215, 254 (Gummow, Hayne and Heydon JJ), 261 (Crennan and Kiefel JJ) (in the context of police officers with statutory powers). Control is important to duty of care issues more generally: Hill $v$ Van Erp (1997) 188 CLR 159, 198 (Gaudron J), 212 (McHugh J), 234 (Gummow J); Perre v Apand Pty Ltd (1999) 198 CLR 180, 195 (Gleeson CJ), 201 (Gaudron J), 326 (Callinan J); Adeels Palace Pty Ltd v Moubarak (2009) 239 CLR 420, 436-7 (French CJ, Gummow, Hayne, Heydon and Crennan JJ). As indicated above, the question of control or lack of it is also critical in decisions of the United Kingdom Supreme Court regarding whether a public authority owes a duty of care: Michael v Chief Constable of South Wales Police [2015] 2 WLR 343, 366 [99] (Lord Toulson, with whom Lord Neuberger, Lord Mance, Lord Reed and Lord Hodge agreed).

152 Vulnerability was also cited by Gummow and Hayne JJ as a critical consideration in the context of whether a statutory authority owed a duty of care: Graham Barclay Oysters Pty Ltd $v$ Ryan (2002) 211 CLR 540, 597 (Gaudron J (570)) and Callinan J (664) agreeing. See also Stuart v Kirkland-Veenstra (2009) 237 CLR 215, 254 (Gummow, Hayne and Heydon JJ) and 260 (Crennan and Kiefel JJ), a decision relating to police officers with statutory powers. Vulnerability is important to duty of care issues more generally: Hill $v$ Van Erp (1997) 188 CLR 159, 186 (Dawson J) (with whom Toohey J agreed (188)); Perre v Apand Pty Ltd (1999) 198 CLR 180, 195 (Gleeson CJ), 201 (Gaudron J), 220, 225 (McHugh J), 259 (Gummow J). See also Jane Stapleton 'The Golden Rule at the Heart of Tort Law: Protection of the Vulnerable’ (2003) 24 Australian Bar Review 135.

153 This is relevant in terms of floodgates arguments. For example, the United States courts have been more likely to recognise a claim where the plaintiffs were specifically known to the defendants as being individuals likely to be affected by the actions of the person released (for example, family members and loved ones), rather than strangers (see discussion at text associated with $\mathrm{nn} 85$ and 86).

154 The High Court did not consider these five issues in McKenna in determining whether a duty of care was owed. Macfarlan JA (with whom Beazley P agreed) considered and applied these factors in the New South Wales Court of Appeal: McKenna $v$ Hunter and New England Local Health District [2014] NSWCA 476, [93]-[95]. 
Regarding the first factor, it is clearly foreseeable that a person with a 20 year history of mental illness and psychosis, who is suffering from hallucinations and is on little medication, might pose a danger to those around him or her. The hospital authorities were aware that Pettigrove was to be released into the care of his friend Rose, and were aware that the two would be sharing a vehicle for a journey of 1200 kilometres. The fact that doctors were conscious that this was risky is borne out by the fact that they made enquiries about the route that would be taken, and were satisfied that there were numerous mental health facilities along the way. (It remains unclear how this would be of assistance if the patient suffered an episode in a place and at a time where it was not possible to obtain the required assistance, something which tragically came to pass). Moreover, surely it was foreseeable that, if the patient did commit violence towards Rose, members of Rose's family would or might suffer psychiatric injury as a result.

Secondly, the public authority had very significant control over Pettigrove. This helps to distinguish the case of Stuart $v$ Kirkland-Veenstra ${ }^{155}$ where the High Court dismissed a claim that police had breached a duty of care that they owed to the plaintiff and her husband. Police had observed the plaintiff's husband in a stationary vehicle with a hose pipe running from the exhaust to the interior of the vehicle, but had declined to exercise their power to detain him, although they believed he was suffering from a mental illness. One of the reasons the Court gave in denying that a duty of care existed was the lack of control that the police had over the husband. This was manifested in the fact that the police did not control the source of the risk to the man, and they did not put the man in harm's way. ${ }^{156}$ Gummow, Hayne and Heydon JJ contrasted this with the position that would have existed if the man had been in police custody and hence under police control. ${ }^{157}$ In McKenna, however, the defendant did control the source of the risk. The police had involuntarily detained Pettigrove and decided to release him. By so doing, they had put those who might come into contact with Pettigrove in harm's way. The defendant had put him in involuntarily detention as the legislation empowered it to do, and had the power to continue to detain him. The power to detain someone against the person's will is one of the most significant powers that a person or organisation can possess in relation to another.

Thirdly, the plaintiffs were vulnerable. They had no control over the release of Pettigrove. They had no means of knowing what condition Pettigrove was

\footnotetext{
155 (2009) 237 CLR 215.

${ }^{156}$ Ibid 255 (Gummow Hayne and Heydon JJ), 261-3 (Crennan and Kiefel JJ).

${ }^{157}$ Ibid 255.
} 
suffering from, and what it might lead him to do. They did not know what medication he was on. There is no evidence that they were aware of his longterm mental health history, or his previous suicide attempts. They had no say in whether Pettigrove was released or not, nor whether he should be released into the care of a friend to share a long journey. There was no way they could protect themselves from the injuries they suffered. They were not in a position to determine the danger that their son/brother was in by volunteering to share this journey as a friendly gesture. They did not have the professional expertise to make this assessment. ${ }^{158}$

Fourthly, the defendant ought to have appreciated that to release Pettigrove when they did posed risks to people like the plaintiffs. They knew he had a 20 year mental illness. They knew he was suffering from psychosis and auditory hallucinations. They knew he often did not take his medication, and was very lightly medicated at the time he was released. They knew he was to embark on a journey of 1200 kilometres in a car, and they knew that being out at night, and being in a confined space, both of which would occur during the journey, would increase the risk of a relapse. If they knew that this presented real risks to the person Pettigrove would share the car with, Rose, then they must have known that, if Rose should suffer serious injury or death, this could well cause psychiatric injury to members of Rose's family. Case law has, eventually, ${ }^{159}$ recognised that death or injury to a person may well lead to psychiatric injury to others who were close to the person, including family members. ${ }^{160}$

The High Court has repeatedly shown concern at the spectre of indeterminate liability. Would recognition of a duty of care in this particular situation create

\footnotetext{
158 Nor, indeed, did Rose, although the claim of Rose's family members is considered independent of any claim that Rose might have had. Some argue that had Rose survived, the defendant might have been able to successfully use the defence of volenti non fit injuria. However, this requires a full appreciation of the risks taken on, and it is unlikely that Rose did fully appreciate the risk, given that he was not an expert in mental health, was not aware of what medication Pettigrove was or was not on, etc. It is likely that he simply relied on the expertise of the defendant in determining, having regard to the risk that the person posed to the defendant and others, that the patient was not suffering a mental illness or mental disorder such as would or might lead to involuntary detention.

159 The days of Chester $v$ The Council of the Municipality of Waverley (1939) 62 CLR 1, where three of the four High Court judges presiding could say that it was not a 'normal' or expected (foreseeable) reaction that a mother would suffer psychiatric injury after seeing her drowned son retrieved from a trench (10 (Latham CJ), 11 (Rich J), 13 (Starke J)), are thankfully long gone.

${ }^{160}$ Jaensch v Coffey (1984) 155 CLR 549; Tame v New South Wales (2002) 211 CLR 317.
} 
indeterminate liability? The answer, it is suggested, is 'no' ${ }^{161}$ The plaintiffs were family members of a victim with whom Pettigrove was sharing a confined space, with the knowledge of the public authority. The victim collected Pettigrove from hospital. One of the doctors had spoken with the victim directly about the travel arrangements. The plaintiffs were family members of the victim. In those circumstances, recognition of a duty of care does not create the spectre of indeterminate liability to an unascertainable class. The class includes the person to whom the mental patient was released, and the family members of that person. It is not necessary to speculate as to whether others are within the class of those who might be able to sue in such a situation. ${ }^{162}$

However, if recent experience with the law of tort has taught us anything, it is that it can be dangerous to try to answer every question in one case, with a comprehensive statement of all the occasions in which liability will be owed for this or that wrong, or with definitive expositions of which principles cover all cases. This is too ambitious a task, at least in this area, and an incremental, case by case approach more consistent with general common law development is now favoured. ${ }^{163}$ Therefore, to say that members of Rose's family were owed a duty of care by the mental health authority in this case is not to comprehensively identify all possible members of the class that might be entitled to sue for a negligent release from mental health care. And it does not raise the spectre of unmanageable, indeterminate liability. Empirical evidence from the United States is instructive here. ${ }^{164}$ It shows that the prospects of successfully suing for negligent failure to protect, or failure to warn, remain low, even in a country often caricatured as being excessively litigious and the home of law suits that defy common sense, yet succeed.

\footnotetext{
161 This was the same answer given by Macfarlan JA in the New South Wales Court of Appeal (with whom Beazley P agreed): 'This concern [regarding indeterminate liability] is not in my view applicable in the present case as the plaintiffs' claim arises out of harm being suffered by a specific individual, Mr Rose, with whom the Hospital had direct dealings and into whose custody the hospital released Mr Pettigrove': McKenna v Hunter and New England Local Health District [2014] NSWCA 476 [97].

162 It should be recalled, however, that the High Court has been prepared to frame the 'class' to whom the duty of care is owed very broadly. An instance was Brodie $v$ Singleton Shire Council (2001) 206 CLR 512, where the duty was framed as being owed by the public authority to users of their roads.

${ }^{163}$ Lord Wright declared the common law way was to go 'from case to case, like the ancient Mediterranean mariners, hugging the coast from point to point, and avoiding the dangers of the open sea of system or science': 'The Study of Law' (1938) 54 The Law Quarterly Review 185, 186; Perre v Apand Pty Ltd (1999) 198 CLR 180, 216-7 (McHugh J).

${ }^{164}$ See n 129.
} 
And fifthly, to find a duty of care here would not intrude on the authority's core policy making or quasi-legislative functions, since it does not have any. This duty of care relates to an operational decision about a particular patient. In terms of the past distinction between policy and operational decisions, it is clearly at the operational end, dealing as it does with the treatment of a particular patient. Recognition of a duty of care works with, and is not at cross-purposes with, the policy in this area that is identified in the relevant legislation. Such policy includes the principle that, in considering whether to subject a person to involuntary detention, the decision maker must consider the risk that the person poses to others. The recognition of such a duty in the United States has proven to be workable.

\section{Other Arguments}

Legislation in the slightly different context of the preventive detention of past sex offenders also gives us some cause for reflection here. (This comparison is not intended to equate those prisoners who have been convicted of a crime, and those who are suffering from mental illness; however some features of the legislation governing convicted sex offenders are relevant). Several states have legislation permitting the court to make an order continuing the incarceration of a past sex offender, based on a psychiatric assessment of the likelihood that the offender will re-offend. For instance, section 11 of the Dangerous Prisoners (Sexual Offenders) Act 2003 (Qld) provides for a psychiatrist's report to be obtained in relation to an application for the detention of a convicted sex offender past the date upon which the offender would otherwise be eligible for release. Section 11(2) indicates that the psychiatrist's report must indicate the level of risk that the offender will commit another serious sexual offence if released. Similarly, section 6(3)(b) of the Crimes (High Risk Offenders) Act 2006 (NSW) requires a report of a qualified psychiatrist, registered psychologist or registered medical practitioner to be obtained which includes an indication of the likelihood of the offender committing further sex offences. These reports help determine whether or not the person is to be released into the general community after a period of involuntary detention.

Two observations can be made regarding these provisions (putting aside arguments regarding the accuracy with which psychiatrists can in fact predict future behaviour, a contested area of debate into which it is not necessary to venture). ${ }^{165}$ Firstly, they reflect the fact that psychiatrists are routinely called

\footnotetext{
165 Bernadette McSherry, 'Sex, Drugs and 'Evil' Souls: The Growing Reliance on Preventive Detention Regimes’ (2006) 32(2) Monash University Law Review 237, 268-9.
} 
upon to make an assessment regarding a person's likely future conduct, including likely wrongdoing that will harm others. Therefore it is clear that recognition of a duty of care in the circumstances in McKenna would not impose on relevant persons a responsibility for which their training makes them unprepared or unqualified. To say this is not to downplay the difficulty of predicting future dangerousness. The American evidence referred to above supports this. ${ }^{166}$ The psychiatrists surveyed indicated that the question of public safety was always paramount in the minds of decision makers considering involuntary detention.

Secondly, this type of legislation requires courts to balance the report of the psychiatric experts with other factors, including (specifically) public safety. ${ }^{167}$ The courts have not found it impossible to balance a range of factors, including: the general expectation that a person who has served the full gaol term to which they have been sentenced will be freed; the expectation that the public will be kept safe; the likelihood of the detainee re-offending; the extent to which the person has been rehabilitated, and so forth. No one says it is easy for a decision maker to balance this range of factors in particular cases, but the legislation clearly contemplates that this kind of balancing exercise will occur. Given this, it does not seem unreasonable to expect a psychiatrist, acting pursuant to legislation permitting involuntarily detention (expressly as a last resort), to have regard to public safety. It is reasonable to expect the psychiatrist to assess the risk that the person already detained or who could possibly be detained under the legislation will offend unless detained. In applying this duty of care, the court would take into account that the legislation specifically states that involuntary detention of someone suffering a mental illness is a last resort. This feature of the legislation should shape the scope and context of the duty of care owed; but it should not preclude it. ${ }^{168}$

Briefly, in Australia in the late 1970s and early 1980s, , the test applied to determine cases of alleged negligence explicitly considered whether questions of public policy negated the existence of a duty of care. ${ }^{169}$ The High Court

\footnotetext{
166 See discussion in the text associated with $\mathrm{nn} 130$ and 131.

167 Dangerous Prisoners (Sexual Offenders) Act 2003 (Qld) s 13(4)(i); Crimes (High Risk Offenders) Act 2006 (NSW) s 9(3)(a).

168 'Proper application of the least restrictive principle should be incorporated, in but not dominate, the evaluation of whether a proper basis for involuntariness was present and therefore whether a reasonable psychiatrist in the psychiatrist's position would have taken the precaution of imposition or maintenance of the person's involuntary inpatient status': Freckelton, above n 144, 289. This reflects the position of Gaudron, McHugh and Gummow $\mathrm{JJ}$ in Brodie (see discussion in the text associated with $\mathrm{n} 50$ ).

${ }^{169}$ Anns v Merton London Borough Council [1978] AC 728.
} 
rejected that approach in Sutherland Shire Council $v$ Heyman, ${ }^{170}$ but there is sporadic express reference to such policy in the case law, ${ }^{171}$ and some justices may be having regard to such matters in reaching their conclusions. Some of the civil liability statutes make express reference to such matters, at least in the context of public authorities. ${ }^{172}$ Clearly policy factors are still relevant in the United Kingdom. ${ }^{173}$ To the extent that public policy is relevant here, it is worth recalling the sentiment of Sir Thomas Bingham MR in $X$ (Minors) $v$ Bedfordshire County Council ${ }^{174}$ - that the rule of public policy which has first claim on the loyalty of the law is that stating that wrongs should be remedied. Clearly, there is strong public interest in upholding high standards in medical endeavours, and legal principle should reflect community expectations. ${ }^{175}$ Individuals expect governments to take reasonable steps to protect their safety. When a duty of care is imposed on virtually all other professionals, it is hard to justify what effectively seems to be a new immunity in the area of mental health service providers. ${ }^{176}$ Recognition that a duty of care exists can have positive benefits in terms of encouraging high standards and appropriate care within a particular field; the opposite also holds. ${ }^{177}$ This point has been the subject of a quantitative study. ${ }^{178}$

170 (1984) 157 CLR 424, 465 (Mason J), 481 (Brennan J), 508 (Deane J), (Gibbs CJ (437) and Wilson J (471) dissenting). In the case of Stuart v Kirkland-Veenstra (2008) 237 CLR 215 (a High Court case involving an allegation against police for failing to exercise a power), there is no mention in any of the judgments about policy considerations that arise with respect to claims against police, in sharp contrast to the United Kingdom case law where consideration of policy has been significant in this context.

${ }^{171}$ Eg Crimmins v Stevedoring Committee (1999) 200 CLR 1, 39 (McHugh J); Graham Barclay Oysters v Ryan (2002) 211 CLR 540, 578 (McHugh J); policy concerns underlie the High Court's maintenance of barrister immunity from suit: D'Orta-Ekenaike $v$ Victoria Legal Aid (2005) 223 CLR 1.

172 Civil Liability Act 2002 (NSW) Part 5; Wrongs Act 1958 (Vic) Part 12; Civil Liability Act 2003 (Qld) Chapter 2 Part 3; Civil Liability Act 2002 (WA) Part 1C; Civil Liability Act 2002 (Tas) Part 9; Civil Law (Wrongs) Act 2002 (ACT) Chapter 8.

173 A recent example appears in Michael $v$ Chief Constable of South Wales Police [2015] 2 WLR 343, 371 [122], explicitly discussing the financial consequences if police were held to owe a duty of care to victims of crime.

${ }^{174}$ [1995] 2 AC 633.

${ }^{175}$ Rogers $v$ Whitaker (1992) 175 CLR 479.

176 Indeed, the general trend has been towards abolishing immunities from suit rather than creating more (Brodie v Singleton Shire Council (2001) 206 CLR 512), though some traditional immunities remain, at least in Australia: D'Orta-Ekenaike v Victoria Legal Aid (2005) 223 CLR 1.

177 Freckelton, above n 144, 289: 'protection from liability in negligence extended to psychiatrists (and the hospitals in which they provide their services) in the McKenna and Presland decisions has gone beyond what is defensible in terms of legal principle, creates a 


\section{CONCLUSION}

The law has in the past been protective of the position of the Crown, in relation to legal liability, as in other matters. While such formal protection has largely been abolished, judicial reluctance to find the Crown liable in negligence remains. This reluctance now appears in different guises, including concerns expressed about resource implications, claims about inconsistency between a public authority's statutory duties and common law liability, and fears of indeterminate liability. This affects those who claim to have suffered loss from the negligence of mental health service providers, since the vast majority of such providers are public authorities. Further common law principles, such as the general reluctance to make one person liable for the actions or omissions of another, create difficulties for those seeking compensation in such circumstances.

Despite these difficulties, courts have been more prepared to find that public authorities owe a duty of care to others when there has evidently been an assumption of responsibility, where control is present, and where the plaintiffs are particularly vulnerable. It has been argued that, according to the factors that the High Court has itself accepted and applied, a mental health authority that has involuntarily detained an individual does have the kind of control over that individual, and has assumed a responsibility towards them, such that injury that the person causes if prematurely and negligently released could be compensable against those authorities.

It has been argued in this article that the High Court's rejection of a recent claim fitting these parameters was incorrect. The High Court was too quick to find an inconsistency between the legislation and a common law duty. It did so upon a clearly selective and incomplete reading of the legislation. It is hard to find that a common law duty of care to family members of a victim of the person released is inconsistent with the legislation when the legislation specifically states that one of the two factors that experts should take into account in deciding whether a mentally ill person should be involuntarily

\footnotetext{
category of lack of accountability that is not conceptually or clinically justified, and may well have undesirably counter-therapeutic consequences'; Freckelton, above n 143, 403.

178 Lucinda Platt, Maurice Sunkin and Kerman Calvo, 'Judicial Review Litigation as an Incentive to Change in Local Authority Public Services in England and Wales' (2010) 20(2) Journal of Public Administration Research \& Theory 243, who concluded that litigation could act as a 'modest driver to improvements in local government services'. The Law Commission also reflected on the potential positive benefits to litigation, in the context of recommendations to streamline the law with respect to public authority liability in private law: The Law Commission, Administrative Redress: Public Bodies and the Citizen, Report No 322 (2010) [4.27].
} 
detained is public safety. The High Court 'dealt with' this inconvenient reality by not discussing those sections of the Act. It suggests an over-keenness to protect the government purse, using inconsistency of obligations as a fig leaf that, annoyingly, does not fit the actual words in the Act. American authorities have considered, and rejected, arguments that the recognition of such a duty of care would conflict with the authorities' duty to their patients. There is empirical evidence suggesting that the recognition of such a duty does not make the life of mental health professionals unbearable, is not unreasonable, and does not impose on them intolerable ethical conflicts. The floodgates have not opened, and it has not led to defensive practice. The High Court would do well to reflect on such evidence, rather than make unjustified assumptions that the research literature does not reflect. Fundamentally, we believe in the rule of law - that legal principles apply to all. The trend in negligence law is away from special privileges for particular groups. The imposition of a duty of care can have positive effects on the quality of care and service provided. The opposite also holds, as this case may tragically reflect. 